NBER WORKING PAPER SERIES

\title{
BANKRUPT INNOVATIVE FIRMS
}

\author{
Song Ma \\ Joy Tianjiao Tong \\ Wei Wang \\ Working Paper 28856 \\ http://www.nber.org/papers/w28856
}

\author{
NATIONAL BUREAU OF ECONOMIC RESEARCH \\ 1050 Massachusetts Avenue \\ Cambridge, MA 02138 \\ May 2021
}

\begin{abstract}
We thank Gustavo Manso (the Editor), an anonymous Associate Editor, two anonymous referees, David Abrams, Shai Bernstein, Alon Brav, Emanuele Colonnelli, Espen Eckbo, Florian Ederer, Mike Ewens, Julian Franks, Pengjie Gao, Xavier Giroud, Paul Goldsmith-Pinkham, Vidhan Goyal, John Graham, Umit Gurun, Edith Hotchkiss, Po-Hsuan Hsu, Victoria Ivashina, Ben Iverson, Yawen Jiao, Josh Lerner, Yueran Ma, William Mann, Rich Mathews, Filippo Mezzanotti, Frank Milne, Ramana Nanda, Marina Niessner, Gordon Phillips, David Schoenherr, Alan Schwartz, Kelly Shue, David Skeel, David Sraer, Amir Sufi, Wing Wah Tham, Heather Tookes, Wenyu Wang, Ting Xu, Dong Yan, and Alex Zentefis for valuable feedback. We also thank seminar participants at AFA (Philadelphia), ALEA (New York), CICF (Hangzhou), Economics of Entrepreneurship and Innovation Conference, EFA (Mannheim), FIRS (Savannah), FOM Conference (Dartmouth), MFA (Chicago), NBER Summer Institute (Corporate Finance; Law and Economics), NFA (Halifax), Queen's, 2nd Rome Junior Finance Conference, Simon Fraser, Tenth Searle Center/USPTO Conference on Innovation Economics, Tsinghua PBC, Wharton, and Yale for helpful suggestions. Carmen Chen, Elaine Cui, Vania Shi, and Shimei Zhou provided valuable research assistance. Ma and Wang acknowledge the financial support of the Social Sciences and Humanities Research Council of Canada (SSHRC). All remaining errors are our own. The views expressed herein are those of the authors and do not necessarily reflect the views of the National Bureau of Economic Research.
\end{abstract}

NBER working papers are circulated for discussion and comment purposes. They have not been peer-reviewed or been subject to the review by the NBER Board of Directors that accompanies official NBER publications.

(C) 2021 by Song Ma, Joy Tianjiao Tong, and Wei Wang. All rights reserved. Short sections of text, not to exceed two paragraphs, may be quoted without explicit permission provided that full credit, including $\odot$ notice, is given to the source. 
Bankrupt Innovative Firms

Song Ma, Joy Tianjiao Tong, and Wei Wang

NBER Working Paper No. 28856

May 2021

JEL No. G33,O32,O34

\section{$\underline{\text { ABSTRACT }}$}

This paper studies how innovative firms manage their innovation portfolios after filing for Chapter 11 reorganization using three decades of data. We find that they sell off core (i.e., technologically critical and valuable), rather than peripheral, patents in bankruptcy. The selling pattern is driven almost entirely by firms with greater use of secured debt, and the mechanism is secured creditors exercising their control rights on collateralized patents. Creditor-driven patent sales in bankruptcy have implications for technology diffusion-the sold patents diffuse more slowly under new ownership and are more likely to be purchased by patent trolls.

Song Ma

Yale School of Management

165 Whitney Avenue

New Haven, CT 06511

and NBER

song.ma@yale.edu

Joy Tianjiao Tong

Ivey Business School

Western University

London, Ontario, N6G 0N1

Canada

jtong@ivey.ca
Wei Wang

Smith School of Business

Queens University

Kingston, Ontario, K7L 3N6

Canada

wwang@queensu.ca

A data appendix is available at http://www.nber.org/data-appendix/w28856 


\section{Introduction}

The growth of the knowledge-based economy depends on the production, allocation, and

exploitation of innovation. However, investment in innovation involves a high degree of uncertainty and risk of failure, which may at times push innovative firms into a state of distress, even when those firms own a substantial number of accumulated innovation assets and possess a large amount of knowledge. The question remains as to what extent these adverse situations impact firms' innovation management, the market for technology, and technology diffusion as a whole.

This paper takes a step forward in understanding the bankruptcy of innovative firms and its implications for technology diffusion. The analysis is guided by two inter-related questions: At the firm-level, are firms able to retain their technologically critical (i.e., core) innovation in bankruptcy reorganizations, and what economic forces drive the reallocation of innovation? Beyond the failing firms themselves, what is the consequence of selling innovation by these firms on the market for technology and technology diffusion?

With these questions in mind, our paper focuses on the role of financial contracting and creditor rights in the bankruptcy process of innovative firms. An emerging literature documents close connections between financial contracts and innovation assets. Patents are often collateralized in debt financing (Mann, 2018), which allows for secured credit to be widely used in the financing of innovative firms (Chava, Nanda, and Xiao, 2017; Hochberg, Serrano, and Ziedonis, 2018). Importantly, secured debt contracts grant creditors control rights that can be exercised against firms in distress, and thus impact the reorganization process of bankrupt innovative firms.

Ideally, the bankruptcy system should help viable firms resolve temporary distress and emerge without losing their valuable assets and growth options. However, the secured creditors' objective is to protect collateral value and to recover debt with certainty. This goal misaligns with the nature of innovative firms - innovation investments are risky; innovation value is option-like; and asset nature is intangible (Acharya and Subramanian, 2009; Brown, Fazzari, and Petersen, 2009). Secured creditors, with incentives to recover their debt, may exert influence on bankrupt firms' ability to retain valuable innovation that they may be 
well-suited to exploit. These creditor-driven sales in turn have important implications for the market for technology and technology diffusion.

We assemble a novel data set using information from the United States Patent and Trademark Office (USPTO), BankruptcyData.com, and Public Access to Court Electronic Records (PACER). Our data contain thirty years of Chapter 11 filings of US public firms that own patents (innovative firms). We collect detailed information on patent portfolios, patent transactions, and the characteristics and collateralization history of these patents. This data set highlights the active patent reallocation of failed innovative firms seeking to reorganize. We observe that firms sell a substantial portion of their patents immediately after their bankruptcy filing. On average, firms sell off $18 \%$ of the patents in their innovation portfolios during bankruptcy reorganization, typically within two quarters after filing.

Our empirical analysis starts with a robust and ubiquitous finding-bankrupt innovative firms are more likely to sell their core (i.e., technologically critical and valuable to the selling firm), rather than peripheral, patents during Chapter 11 reorganization. We determine core patents using the measure developed and validated in Akcigit, Celik, and Greenwood (2016) and Brav, Jiang, Ma, and Tian (2018). This measure is built on the technological proximity between a patent and the owning firm's core innovation expertise, and core patents are shown to be crucial for firm value. Our patent-level analysis shows that patents in the highest quartile of the core measure are $30 \%$ more likely to be sold compared to the baseline selling rate of an average patent. The pattern cannot simply be explained by patent-level characteristics, like redeployability or liquidity, that may influence the selling decision.

The pattern of selling core innovation in bankruptcy is diametrically opposed to patterns observed in non-bankrupt firms (Akcigit, Celik, and Greenwood, 2016; Brav et al., 2018). Why do bankrupt innovative firms sell their core patents, the very patents that one would assume could help firms recover? More specifically, what is the role of creditor control and financial contracting in this process?

We start by investigating whether the patent selling pattern differs by the extent that secured debt is used in a firm's capital structure. We find that the selling of core patents concentrates in firms with an above-median level of secured debt scaled by total debt (secured debt ratio). In firms with an above-median secured debt ratio, core patents are $110 \%$ more 
likely to be sold, more than tripling the economic magnitude in the baseline. Core patents are in fact less likely to be sold in firms using less secured debt, in parallel with what happens in non-distressed firms. In addition, we divide our sample by the turn of the century and find that the selling of core patents is pronounced only after 2000. The is consistent with the strengthening of creditor rights in bankruptcy and major updates to the Uniform Commercial Code enabling secured creditors to foreclose intangible collateral since the late 1990s.

Together, this evidence lends initial support to an explanation that creditor rights play an important role in patent reallocation in bankruptcy, casting doubt on the conventional view that bankrupt firms divest assets through $§ 363$, a section of the Bankruptcy Code that allows bankrupt firms to sell assets "free and clear of liens," at their own will. We recognize that bankruptcy and the level of secured debt are endogenously determined, making it difficult to make causal claims about how creditor rights affect the sale of core patents. Ideally, we need exogeneous variation to bankruptcy filings or to creditor rights. Without the fortune of having such a setting, we further our analysis with an arguably more direct approach - we examine two creditor-specific mechanisms: enforcing patent collateralization and creditors recontracting. We also show that the results reverse when creditor incentives are aligned with shareholders.

First, even though secured creditors possess significant rights in bankruptcy, their ability to influence asset sales is bounded by their rights on the collateralized assets. In other words, collateralized patents are more vulnerable than other assets to creditor rights. We show that the creditors' influence is exerted through creditors enforcing their rights on patent collateral. We find that a firm's core patents are more likely to be ex ante pledged as collateral for debt financing. Firms in bankruptcy are seven times more likely to sell a collateralized patent than non-distressed firms. Importantly, core patents are not more likely to be sold in bankruptcy if they are not collateralized. Moreover, we find that the selling of collateralized patents is more pronounced in firms that use more secured debt. The evidence combined shows that enforcing creditor rights on patent collateral is a key driver behind the selling of core patents.

The second mechanism that allows creditors to directly influence the selling of core patents is through debtor-in-possession (DIP) financing, an effective recontracting tool for creditors to reinforce their rights in bankruptcy. Prior studies show that DIP contracts, typically 
provided by existing lenders, contain extensive and restrictive covenants and milestones that grant significant control rights to lenders. In some cases, DIP lenders have a say on $§ 363$ asset sale decisions and require the bankrupt firm to use the proceeds to repay existing debt. The DIP financing contract undoubtedly helps reinforce creditor rights. Our results show that among firms with a high secured debt ratio, the ones with DIP financing have a 10 percentage points higher probability of selling core patents than those without DIP financing.

The effect of secured debt on patent sales is related not only to the rights provided by the financial contracts but also the incentives of creditors in exercising such rights. The effect of creditor rights should be weaker when secured creditors' interests are more aligned with those of junior creditors. We investigate whether the selling pattern differs when secured debt is likely the fulcrum class and thus becomes residual claims of the reorganized entity. We adopt two ex post measures using recovery information in reorganization plans and an ex ante measure using the collateralization level of secured debt. The likelihood of a core patent being sold is significantly lower when secured creditors do not recover their claims in full or receive newly issued equity of the emerged firm, and when secured debt is under-collateralized at Chapter 11 filing. Moreover, core patents are less likely to be sold in prepackaged cases where all creditors agree to a reorganization plan before Chapter 11 filing.

A natural implication of creditor-driven innovation reallocation is its long-term impact on the functioning of the market for technology and the diffusion of technology. In the last part of the paper, we explore the exploitation of the technology around patent sales and the buyers of the patents sold in bankruptcy.

We find that technologies sold in bankruptcy diffuse slowly after selling. Patents sold during bankruptcy experience a sharp decline in year-over-year citations post transaction. However, this does not mean that those sold patents are of poorer quality-in fact, there is a strong and robust increasing trend in the total number of citations before the sale ("up then down"), supporting an interpretation that the sold patents are high-quality "hot" patents that are poorly used after the sale. In contrast, citations made to patents sold by non-distressed firms, including those sold by bankrupt firms three years before their bankruptcy filing, show a distinct pattern - citations decrease under old ownership and improve after reallocation ("down then up"). We also find that patents sold during bankruptcy are more likely to be 
purchased by patent trolls than by practicing users, and that these patents are used mainly for litigation rather than production. Purchasing high-quality patents appears to be a strategy for patent trolls to accumulate their patent portfolios - which fuels concern about patent trolls for the innovation ecosystem (Cohen, Gurun, and Kominers, 2019).

This paper connects to the literature on how financial contracting affects corporate policies (Roberts and Sufi, 2009a; Nini, Smith, and Sufi, 2009, 2012), operational flexibility (Benmelech, Kumar, and Rajan, 2020), and most importantly, innovative activities (Chava, Nanda, and Xiao, 2017; Hochberg, Serrano, and Ziedonis, 2018; Mann, 2018). We are the first to document how debt contracts affect the patent portfolios of bankrupt innovative firms. The finding that firms sell core patents highlights that creditor rights and patent collateral can be ex post beneficial to secured creditors but may have significant consequences to innovative firms and technological diffusion, laying out an important tradeoff in the process of financing innovation (Acharya and Subramanian, 2009; Ederer and Manso, 2011).

Our paper also adds new evidence to the literature on the market for technology and technology diffusion (Gans and Stern, 2010; Arora, Fosfuri, and Gambardella, 2004). The prior literature, focusing mainly on normal times, portrays a well-functioned market for technology (Serrano, 2010; Akcigit, Celik, and Greenwood, 2016; Brav et al., 2018; Figueroa and Serrano, 2019). We add to this literature by providing evidence that bankrupt innovative firms actively participate in innovation transactions and show distinct selling patterns. Our evidence suggests that financiers exert influence on innovation transactions and post-sale technology diffusion, warranting a closer examination of the interaction between financial markets and the technology market.

Finally, our findings shed light on asset allocations in bankruptcy. Maksimovic and Phillips (1998), Pulvino (1999), Ramey and Shapiro (2001), Gilson, Hotchkiss, and Osborn (2016), and Bernstein, Colonnelli, and Iverson (2019) study challenges that firms face in reallocating assets in bankruptcy. Benmelech and Bergman (2011), Meier and Servaes (2019), and Bernstein et al. (2019) show that reallocation decisions not only affect the bankrupt firms but also spill over to other firms. Our paper contributes to this literature in three ways. First, our study focuses on the reallocation of patents, which is a growing class of firm assets. Second, we highlight the role of creditors, while the existing literature mainly focuses on 
asset trading frictions arising from industry condition or market thickness. Third, our results present another channel through which corporate bankruptcies can spill over to the economy, that is by affecting the market for technology and technology diffusion.

\section{Data}

\subsection{The Sample of Bankrupt Firms}

We retrieve all Chapter 11 bankruptcies filed by US public firms from 1981 to 2012 from New Generation Research's Bankruptcydata.com. The sample firms are manually matched with Compustat using firm names and company information, and we remove firms that do not have a valid identifier in Compustat. This initial screening results in 2,169 Chapter 11 cases. We remove cases that were dismissed or pending (151 cases), were merged into another leading case (2 cases), or had unknown outcomes (158 cases). We also remove financial firms (161 cases) as they are less relevant in a study of industrial innovation. We then exclude cases with unavailable or incomplete dockets from Public Access to Court Electronic Records, i.e., PACER (74 cases). This process leaves us with a sample of 1,623 cases, including both large, mature corporations and entrepreneurial companies that just went public. $^{1}$

We collect key information on the timeline and characteristics of the bankruptcy case from Bankruptcydata.com and PACER, including the date of Chapter 11 filing, whether the case is prepackaged, ${ }^{2}$, assets at bankruptcy filing, the outcome of reorganization, the confirmation date and effective date of the reorganization or liquidation plan, and the conversion date for those cases converted to Chapter 7 . From reorganization plans and liquidations plans that are confirmed by the court, we are able to determine debt recovery rates and whether a particular class of creditors received new equity as compensation for its impaired claims for a subsample of our firms. ${ }^{3}$

\footnotetext{
${ }^{1}$ Our data set is the largest bankruptcy data set for US public firms with detailed case information, twice as large as that listed in the widely used UCLA-LoPucki Bankruptcy Research Database, which covers Chapter 11 filings by US public firms with $\$ 100$ million in assets in constant 1980 dollars for the sample period. The ability to include smaller firms is particularly important because many smaller entrepreneurial firms own many patents.

${ }^{2} \mathrm{~A}$ bankruptcy case is defined as prepackaged if the debtor drafted the plan, submitted it to a vote of the impaired classes, and obtained the acceptance necessary for consensual confirmation before filing.

${ }^{3}$ See Jiang, Li, and Wang (2012) for discussions on how recovery rate for a particular creditors class is
} 
We use Compustat for financial statement data reported as of the last fiscal year before the bankruptcy filing to construct ROA (return on assets, calculated as the ratio of EBITDA to book assets), and R\&D/Assets (R\&D expenses scaled by book assets). We resort to Capital IQ (capital structure details section) and last 10-K or 10-Q filings through EDGAR to compile detailed information on a firm's debt structure immediately before bankruptcy filing. We manually identify the following debt types: drawn bank revolvers, term loans, secured bonds and notes, capital leases, other secured debt, unsecured bonds and notes, and total debt, and we collect information on their security and seniority status. Secured debt ratio is defined as the sum of the outstanding amount of drawn bank revolvers, term loans, secured bonds and notes, capital leases, and other secured debt, scaled by the total debt amount. This variable captures the use of secured debt in a firm's debt structure (Colla, Ippolito, and Li, 2013; Carey and Gordy, 2016; Gilson, Hotchkiss, and Osborn, 2016). The variable is only available for the years after 1995 due to the availability of 10-K and 10-Q filings on EDGAR. All variables are winsorized at the 1\% and $99 \%$ levels.

We determine whether a Chapter 11 firm obtains DIP financing using court dockets retrieved from PACER. Specifically, we search for key phrases that can help to identify whether the debtor filed a motion on DIP financing and whether a judge approved it. ${ }^{4}$ We also resort to bankruptcy plans and news in LexisNexis and Factiva for information on DIP financing.

For a subsample of firms with electronic dockets and documents downloadable on PACER, we identify whether any asset sale through $\S 363$ is conducted. After manually processing thousands of documents on $§ 363$ sale motions and orders, we are able to identify 540 sale motions with 518 (by 151 unique firms in our sample) approved by the judge. We determine the nature of assets sold in these transactions and code each sale as either "innovation" or "no innovation" based on whether patents are listed in the $§ 363$ sale motions and their attachments. Moreover, we determine whether objections are filed in court against a sale using court dockets and identify the key constituents (e.g., UCC, individual unsecured creditors, calculated.

${ }^{4}$ These key phrases include: debtor-in-possession financing, DIP financing, post-petition financing, secured financing, secured lending, post-petition finance, and secured finance. See Li and Wang (2016) for a detailed description. 
governments) that file such objections.

\subsection{Patent Data and Key Measurements}

We construct patent-holding information of each firm using the National Bureau of Economic Research (NBER) patent database and Bhaven Sampat's patent and citation data, both of which are originally extracted from the USPTO. The combined data are linked to the public firm universe using the bridge file provided by NBER, allowing us to establish the full list of patents that a firm owns at each point in time between 1976 and 2012. The database categorizes each patent into one of 430 technology classes based on the underlying fundamental feature of the innovation. It also records the number of lifetime citations received by each patent and the sources of those citations, which help identify the level of utilization and the potential users of each patent.

When owners sell their patents, they file patent reassignment documents with the USPTO. The original USPTO patent reassignment database provides information useful for identifying patent transactions: the assignment date; the participating parties, including the transaction assignee ("buyer") and assignor ("seller"); and comments on the reason for the assignment. We merge the raw assignment data with the Harvard Business School inventor database and the USPTO patent database to gather additional information on the original assignees.

We then follow a procedure, similar to that of Brav et al. (2018) and Ma (2020), in which we identify patent transactions from all patent reassignment records from 1976 to 2015. Importantly, the identified patent transactions do not include cases involving an internal patent transfer, either from an inventor to his/her employer or between two firm subsidiaries. This step is crucial for our study because bankrupt firms are more likely to undergo organizational changes during this period. For example, we ensure that such cases as "General Motors Corporation" reassigning its patents to "General Motors Global Technology Operations" are not counted as patent transactions. ${ }^{5}$ We follow Mann (2018) to identify

\footnotetext{
${ }^{5}$ We provide a detailed description of the data and methodology in the Online Appendix. Graham, Marco, and Myers (2018) provide a detailed discussion on the USPTO patent reassignment records from the perspective of the data administrator. One potential limitation of this database is that recording a transaction in the USPTO is not mandatory. However, both statute and federal regulations provide strong incentives for reporting in order to claim property rights. These incentives to completely report are particularly strong for firms in distress and bankruptcy when clean property rights are crucial.
} 
patents that are used as collateral and the exact timing of the loan.

\subsubsection{Measuring "Core Patents"}

The most important patent-level measure in this study captures whether a patent is core or peripheral to its owning firm. The Core measure intends to capture the importance of a patent in the owning firm's technology portfolio; thus it is mostly comparable among patents within a firm's own patent portfolio. A patent can be core and valuable to one firm's central business but it may be peripheral and less valuable in other firms' innovation portfolios.

We follow Akcigit, Celik, and Greenwood (2016), who formalize the distance between a patent $p$ and a firm $i$ 's overall technological expertise using a generalized mean of distances between $p$ and each other patent in firm $i$ 's patent portfolio. Specifically, we use the following definition:

$$
d_{t}^{\iota}(p, i)=\left[\frac{1}{\left\|P_{i t}\right\|} \sum_{p^{\prime} \in P_{i t}} d_{\text {class }}\left(\text { Class }_{p}, \text { Class }_{p^{\prime}}\right)^{\iota}\right]^{\frac{1}{\iota}},
$$

where $P_{i t}$ denotes the patent portfolio of all patents that are owned by firm $i$ in year $t\left(\left\|P_{i t}\right\|\right.$ is the size of the portfolio). $\iota \in(0,1]$ is the power of the generalized mean operator. Following the prior literature, we use $\iota=0.66$ to calculate the primary measure while all the results are both qualitatively and quantitatively similar using other $\iota$ parameters.

The key component in the definition, $d_{\text {class }}\left(\right.$ Class $_{p}, C$ lass $\left._{p^{\prime}}\right)$, stands for the distance between a patent pair $p$ and $p^{\prime}$. The distance operator $d_{\text {class }}(X, Y)$, as defined in Akcigit, Celik, and Greenwood (2016), is the symmetric distance metric between two technology classes, $X$ and $Y$, and is calculated based on citation patterns of $X$ and $Y$. Let $\#(X \cap Y)$ denote the number of all patents that cite at least one patent from classes $X$ and $Y$ simultaneously, and $\#(X \cup Y)$ denote the number of all patents that cite at least one patent from class $X$ and/or $Y$, and

$$
d_{\text {class }}(X, Y)=1-\frac{\#(X \cap Y)}{\#(X \cup Y)}
$$

Intuitively, this measure means that if each patent that cites $X$ also cites $Y\left(d_{\text {class }}(X, Y)=\right.$ 0 ), then $X$ and $Y$ are highly close in their role in the innovation space, and vice versa. 
$d_{\text {class }}\left(\right.$ Class $_{p}$, Class $\left._{p^{\prime}}\right)$ in Eq. (1), therefore, is calculated based on the classes of $p$ and $p^{\prime}$.

We define $1-d_{t}^{\iota}(p, i)$ as the main Core measure for each patent $p$ in firm $i$, and the higher this measure is, the closer the patent is to the firm's core innovation assets. We also create a dummy variable $I$ (Core), which takes value one if the patent is in the top quartile of Core among all patents owned by the firm in each year, and zero otherwise. In our empirical analysis, we present results using both the continuous measure and the dummy.

\subsubsection{Measuring Patent Quality and Liquidity}

We use patent citations to measure the general quality of a patent. Specifically, our measure Scaled Citation is defined as the number of citations received in the first three years of a patent's life, scaled by the three-year citation of patents from its own vintage and technology class. I(YoungPatent $)_{p t}$, an indicator variable that equals one if the patent was granted within the past six years, captures patent age (Serrano, 2010). Redeployability captures the extent to which a patent $p$ is redeployable and valuable to other potential users of the innovation. Specifically, we define patent-level Redeployability $y_{p}$ as one minus self-cite ratio, where self-cite ratio is the share of citations that patent $p$ receives from the follow-on patents issued to the same company within the first three years after being granted. MFTLiquiditypt, a patent-year-level variable, is used to capture the annual likelihood that a patent $p$ could be sold in year $t$ in the market for technology. We follow Hochberg, Serrano, and Ziedonis (2018) to compute this MFT Liquidity measure as the ratio of transacted patents over the patent population in each technology class and issue year, which we can then uniquely map to each patent $p$ at each time point $t$.

\subsection{Active Sales of Patents in Bankruptcy}

We merge our sample of 1,623 Chapter 11 filings by US public firms with the USPTO patent database and require each Chapter 11 firm to own at least one patent at the time of bankruptcy filing. The screening results in a final sample of 518 innovative firms. Figure 1 presents the annual distribution of both innovative and non-innovative firms. The figure shows a strong cyclical pattern, with the number of bankruptcy filings of both types of firms reaching high levels during economic recessions such as those in the early 1990s, early 2000s, 
and 2008-2009. The bankruptcies of innovative firms account for a larger fraction of total filings after year 2000 (36\%) than before it (29\%).

\section{[Insert Figure 1 Here.]}

Before going into any analysis, we describe the sample by characterizing the dynamics of selling patents around bankruptcy. Table 1 presents bankrupt firms' intensity of selling innovation, tabulated based on their Fama-French 12 Industry categorization (Panel A), and based on the year of bankruptcy filing (Panel B). In each panel, we show the total number of Chapter 11 cases, the number of cases filed by innovative firms, the proportion of firms that sold patents during bankruptcy reorganization, and the percentage of patents sold. ${ }^{6}$

\section{[Insert Table 1 Here.]}

Selling patents during bankruptcy is a surprisingly pervasive phenomenon. Forty percent of firms sell at least one patent in Chapter 11 reorganization, and transacted patents account for $18 \%$ of their patent stock. The proportion of firms that sell patents and the percentage of patents transacted has remained at a fairly stable level since the early 1980s. A cross-sectional comparison in Panel A suggests that the intensity of selling patents in bankruptcy varies across industries. Health care, drug, and medical device companies sell their innovation more than any other industries, with $56 \%$ of firms conducting such activities and almost $30 \%$ of their patent portfolios being sold. But even in the industries that have the lowest patent selling intensities during bankruptcy (Wholesale and Retail, Consumer Non-durables), nearly $25 \%$ of firms sell more than $15 \%$ of their patent holdings. A time-series analysis in Panel B suggests that patent sale, even though largely overlooked in academic studies, is not a new phenomenon.

We next construct a firm-quarter panel of all US public firms that have at least one granted patent from the USPTO (that is, a firm is included in the sample after its first patent is issued) to examine the selling intensity of bankrupt firms compared to other patent-holding firms and the non-bankrupt periods. We exploit the following model in the same panel sample of firm $i$ and quarter $t$ :

\footnotetext{
${ }^{6}$ The ratio of sold patents is defined as zero for firms that sold no patents.
} 


$$
\text { Sold }_{i t}=\sum_{k=-4}^{4} \beta_{k} \cdot d[t+k]_{i t}+\lambda \times \text { Control }_{i t}+\alpha_{i}+\alpha_{t}+\varepsilon_{i t},
$$

where $\operatorname{Sold}_{i p}$ is a dummy variable indicating whether patent $p$ is sold during bankruptcy reorganization by its owning firm $i ; \alpha_{i}$ and $\alpha_{t}$ are firm and year fixed effects, respectively, and the independent variables of interest are the set of dummies, $d[t-4], \ldots, d[t+4]$, indicating whether the firm-quarter observation fits into the $[-4,+4]$ time frame of the bankruptcy event.

\section{[Insert Figure 2 Here.]}

The selling pattern is reported in Figure 2. Even though it takes about 16 months for our sample firms to reorganize in Chapter 11, the increase in patent sales concentrates in the first two quarters after the bankruptcy filing, as indicated by the strongest results in $t+1$ and $t+2$, and it decays quickly afterward. Our estimates show that the probability of selling a patent is $9.6 \%$ higher than the benchmark (i.e., non-bankrupt firms) in $t+1$. Comparing coefficients for $d(t-1)$ and $d(t+1)$, we find that the probability of selling increases more than sixfold. The F-test suggests that the six-time increase in probability is statistically significant at the $1 \%$ level; at the intensive margin, the increase is even more dramatic. Importantly, we do not observe any secular trends before bankruptcy filings in Figure 2.

The fast selling of patents is consistent with both institutional features of the bankruptcy process and the nature of innovation assets. First, patent sale in our analysis mostly captures $\S 363$ sales that require a judge's approval but not formal voting, which significantly simplifies the sale procedure and reduces the time required for conducting the sale. ${ }^{7}$ Second, because secured creditors are concerned with the value erosion of their collateral, and since innovation assets are particular vulnerable due to their option-value nature and value uncertainty, secured creditors have strong incentives to push for the sale of such assets immediately after filing. Debtor management, on the other hand, would agree to sales since secured creditors are typically granted "adequate protection" for their security interests, which puts constraints

\footnotetext{
${ }^{7}$ In practice, patent sales are typically conducted through $§ 363$ of the Bankruptcy Code, and those sales constitute our main data sample. Anecdotally, well-known, large-scale innovation sales in bankruptcy, such as those of Eastman Kodak and Nortel, were conducted through §363. In the Online Appendix, we provide a detailed discussion of the $\S 363$ sale process and the economics therein.
} 
on management actions. Finally, DIP financing contracts often include specific clauses and conditions on asset sales, which require the debtor to conduct sales of certain assets immediately after filing.

\section{[Insert Figure 3 Here.]}

To shed light on how the selling behavior of patents compares to those of other assets, we compare the dynamics of innovation sales and other asset sales through $\S 363$ using sale documents collected from court. Figure 3 plots two metrics: 1) the total number of $\S 363$ sales from the quarter of filing to four quarters after filing and 2) the quarterly ratio of innovation-related $\S 363$ sales to total $\S 363$ sales. We find a similar timeliness of asset sales in the quarterly number of $\S 363$ sales. More interestingly, innovation-related sales occur with greater intensity immediately after bankruptcy filings. In the quarter of filing, nearly $60 \%$ of $\S 363$ sales are innovation-related, but by the fourth quarter after filing, this ratio drops to 17\%. Overall, the pattern suggests that patents appear to be front-loaded in asset sales.

\section{The Selling of Core Patents}

\subsection{Summary Statistics}

Table 2 Panel A reports summary statistics of the patent-level data set. This data set covers all patents owned by 518 innovative bankrupt firms that have non-missing values of key patent-level variables. The pooled average of Sold is 0.083 , meaning that $8.3 \%$ of all patents owned by a bankrupt firm at filing are sold. ${ }^{8}$ The average of Core with parameter $\iota=0.66$ is 0.444, comparable to earlier studies such as Akcigit, Celik, and Greenwood (2016). The variable has large cross-sectional variations with a standard deviation of 0.274 . Moving from the 25 th percentile to the 75 th percentile of the variable will increase the measure by more than three times. A similar pattern holds with parameter $\iota=0.33$. Given that $I$ (Core) is constructed to indicate the top quartile of Core, the mean scores are at 0.25.

More than $30 \%$ of patents are collateralized at the time of bankruptcy. About $25 \%$ of the patents in the patent portfolio are six years or younger at the time of bankruptcy filing. The

\footnotetext{
${ }^{8}$ This ratio is different from the $18 \%$ reported in Table 1 , which is calculated using unweighted firm-level observations.
} 
average value of redeployability is 0.789 ; this suggests that, on average, $78.9 \%$ of citations received by a patent are made by other firms, i.e., external citations. The average MFT Liquidity of a patent is 0.033 , which means that, on average, $3.3 \%$ of patents in a technological class are transacted in a specific year. There is also a large cross-sectional variation in this liquidity measure, with standard deviations of around 0.022 , and a large jump from the 0.021 at the 25 th percentile to 0.039 at the 75 th percentile.

\section{[Insert Table 2 Here.]}

Panel B of Table 2 describes the 518 innovative bankrupt firms in the sample. About $8.9 \%$ of the cases are prepackaged filings. The bankruptcy cases, on average, stay in the reorganization process for 511 days. The case outcomes are: $13 \%$ acquired, $12 \%$ converted to Chapter 7, 51\% emerged, and 24\% liquidated in Chapter 11. Secured debt accounts for 53\% of total debt, on average. ${ }^{9}$

Our sample firms are large in general, having $\$ 973$ million in book assets at filing on average and a median value of $\$ 94$ million. They own, on average, 175 patents at the time of filing for bankruptcy; the median patent holding is 13, suggesting a highly skewed distribution of firm size and patent stock. ${ }^{10}$ In addition, a typical firm in our sample experiences negative ROA at the time of Chapter 11 filing. Secured accounts for $53.2 \%$ of total debt. ${ }^{11}$

\subsection{Baseline Results}

Our first question asks whether firms are able to retain valuable core innovation in bankruptcy. We approach this question by examining the characteristics of patents that firms sell in bankruptcy. The analysis is performed on a patent-level cross-sectional data set. Each observation is a patent $p$ in a bankrupt firm $i$ 's patent portfolio in the year of filing. We

\footnotetext{
${ }^{9}$ Our statistics are in line with those reported by prior studies. For example, Carey and Gordy (2016) report a mean of $48 \%$ of the fraction of secured debt in their sample that is based on S\&P LossStats and Moody's Ultimate Recovery databases.

${ }^{10}$ The eventually liquidated firms are typically much smaller in size and patent holdings, so the results in the paper are primarily driven by the firms that eventually emerge. The distinction among all the outcomes will be controlled for and explored in the empirical analyses.

${ }^{11}$ In Appendix Table A.3 we compare those innovative bankrupt firms with other bankrupt firms. Those firms are very similar to each other in terms of case and firm characteristics. Innovative bankrupt firms are, however, more R\&D heavy, more likely to obtain DIP financing, and less likely to be converted from Chapter 11 to Chapter 7 liquidations.
} 
estimate the following linear probability model:

$$
\text { Sold }_{i p}=\alpha_{i}+\beta \cdot \text { Core }_{i p}+\lambda \times \text { Control }_{i p}+\varepsilon_{i p} .
$$

The key explanatory variable is Core, for which both the continuous and categorical versions are used. We control for patent characteristics, including Scaled Citation,$I$ (YoungPatent $)_{p t}$, Redeployability, MFTLiquidity, and firm-specific patent transaction intensities using firm-level fixed effects. Standard errors are clustered at the firm level.

[Insert Table 3 Here.]

Table 3 presents the regression results of Eq. (3). ${ }^{12}$ Column (1) shows that Core is a strong and positive determinant of whether a patent is likely to be reallocated during bankruptcy reorganization. The coefficient of 0.022 translates a change of Core from the 25th percentile to the 75 th percentile to a 1 percentage point $(0.022 \times(0.673-0.213))$ increase in the probability of selling, which is a $12.2 \%$ jump based on the unconditional probability (8.3\%). In column (2), we exploit categorized variables by cutting patents into within-firm quartiles based on Core and creating dummy variables to indicate the quartiles. The dummy indicating the lowest quartile is omitted, and this set of patents serves as an effective benchmark. Core (4th Quartile), also denoted as I(Core), dominates the patent-selling decision. Being one of the top-quartile core patents increases the probability of sale by 2.5 percentage points, which is a $30.1 \%$ jump based on the unconditional probability.

In column (3), we use a Core measure defined by whether that patent belongs to the top technological class that the firm innovates in, similar to that in Brav et al. (2018). We find that core patents are 1.6 percentage points more likely to be sold, comparable to that in column (2). The analysis introduces additional controls for patent-level characteristics in columns (4) and (5). This is important since without those explicit controls, core patents may be proxying for patent-level fundamentals that could affect the salability. We find that the pattern of selling off core patents remains robust.

\footnotetext{
${ }^{12}$ In Appendix Table A.7, we show that the results are robust if we limit the sample to only firms that own at least 5,10 , or 20 patents at the time of bankruptcy filing.
} 
In columns (6), we repeat the analysis using only firms that eventually emerged from the bankruptcy process. The goal of the emerging-firm analysis is to mitigate the concern that firms that are eventually liquidated may place everything for sale without discretion. The liquidation decision can then bias the estimation. Note that $51 \%$ of firms emerged from Chapter 11, but they own more than $85 \%$ of patents in the sample due to the fact that most large and innovative firms emerged from bankruptcy reorganization.

We show that even among firms and patents that are most economically viable and therefore are least likely to want to switch course, the pattern of selling core patents remains robust. We focus on firms that appear to suffer financial but not economic distress, empirically defined in our sample as top-tercile leverage with top-tercile ROA (Asquith, Gertner, and Scharfstein, 1994; Andrade and Kaplan, 1998). These firms typically use the bankruptcy system to resolve temporary liquidity and capital structure issues, and they are less likely to change their business. We find that these firms also lose their core patents, as shown in column (7) of Table 3. ${ }^{13}$ In column (8) of Table 3 we show that even among the most recent patents, the pattern of selling core patents remains robust.

The pattern of selling core innovation presented in Table 3 is in sharp contrast to the evidence from Akcigit, Celik, and Greenwood (2016) and Brav et al. (2018) that firms sell peripheral (non-core) patents during normal times. In Appendix Table A.5, we expand our bankruptcy-only sample to patents owned by all patenting firms between 1981 and 2012. We confirm that core patents are less likely to be sold in normal times, and the pattern of selling core patents holds only during the bankruptcy period.

\subsection{Financial Contracting, Creditor Rights, and Patent Sales}

Why do innovative firms in bankruptcy sell off their core patents, the very patents that one would presume to help them to recover and stay competitive? Our primary hypothesis centers around the effects of financial contracting, particularly secured creditor rights, in bankruptcy. The view that firms sell core patents due to creditor rights is rooted in the incompatibility between debt and innovation assets (Hall and Lerner, 2010; Kerr and Nanda, 2015). Conceptually, Acharya and Subramanian (2009) show that in bankruptcy, secured

\footnotetext{
${ }^{13}$ We acknowledge that our measures cannot perfectly capture all firms that suffer pure financial distress.
} 
creditors, who are granted control rights to collateral, prefer to recover debt with certainty through selling innovation assets rather than maximizing the value of the going concern.

We run our main specifications separately for firms with high and low secured debt ratio (defined in Section 2), and test whether the intensity of selling core patents differs in two subsamples. In addition, we present results in which we interact measures for core patents with the high secured debt ratio dummy. To allow full flexibility, we also interact all other control variables with the high secured debt ratio dummy. With this setup, the coefficient for Core $\times$ High (a dummy indicating high secured debt ratio) tests whether the pattern of selling core patents differs by the use of secured debt. Table 4 Panel A presents the results.

\section{[Insert Table 4 Here.]}

We find that the selling of core patents is almost entirely driven by firms with abovemedian secured debt ratio. The coefficient estimates for Core and $I$ (Core) in the subsample of firms with high secured debt ratios are statistically significant and more than double in magnitude compared to those presented in the baseline regressions in Table 3. In contrast, in firms with low secured debt ratios, the selling probability is either independent of, or negatively related to, a patent being core. The positive interaction terms in columns (3) and (6) are large and statistically significant at the $1 \%$ level, consistent with the estimates from the subsample tests. Column (6) provides an easy interpretation of the economic magnitude - a core patent is 8.1 percentage points more likely to be sold if the secured debt ratio is high. ${ }^{14}$

In the second set of tests, we divide our Chapter 11 sample by the turn of the century and make intertemporal comparisons. This intertemporal division is motivated by two sets of studies on financial contracting and creditor control rights. First, studies show that the Chapter 11 system has become more creditor friendly since the late 1990s (Baird and Rasmussen, 2002; Roberts and Sufi, 2009b; Bharath, Panchapagesan, and Werner, 2014). Second, major updates to Article 9 of the Uniform Commercial Code in 2001 and state adoptions afterward help firms better deal with security interests in intangible assets and ease the way for secured creditors to foreclose on collateral in case of default (Mann, 2018).

\footnotetext{
${ }^{14}$ To partially mitigate the concern that firms with high levels of secured debt are different than those with low levels of secured debt, in Appendix Table A.6 we show that firms with high vs. low levels of secured debt are observably similar to each other.
} 
In Panel B of Table 4, we find that the selling of core patents is pronounced only from the 2000s to the present. In contrast, firms that filed for Chapter 11 before 2000 are not more likely, and even are less likely, to sell core patents. This evidence complements that presented in Panel A, showing the selling of core patents is prevalent with the strengthening of creditor rights in recent decades. ${ }^{15}$

Our results highlight the effect of debt contracting on patent sales by innovative firms. The evidence casts doubt on the conventional view that firms use $\S 363$ of the Bankruptcy Code to divest assets and raise capital of their own will. If this were the case, firms' selling behavior should not depend on the control rights of creditors. Our findings suggest that secured creditors, who are protected by the debt contract and collateral, play an important role in the selling of core patents in bankruptcy. The $\S 363$ sale, in fact, may have provided an effective tool ex post for creditors to enforce their rights.

However, we want to give the caveat that, in order to identify the effect of creditor rights in selling core patents, we need exogeneous variation to bankruptcy filing decisions or to creditor rights in bankruptcy. Without the fortune of having such a setting, we further our analysis with an arguably more direct approach. In the next section, we explore two specific mechanisms through which secured creditors enforce their contractual rights to further examine the role of debt contracting in patent sales.

\subsubsection{Mechanism from Contracting 1: Patent Collateralization}

We first establish the impact of creditor rights through exploring a mechanism that is unique to secured creditors - patent collateral and the enforcement of rights on collateralized assets in bankruptcy. For the collateral mechanism to drive the selling of core patents, the economic reasoning needs to be supported in two steps: core patents must be collateralized ex ante for credit, and creditors enforce their rights on collateral ex post.

We first investigate whether core patents are more likely to be collateralized. In Table 5 Panel A, we perform a patent-level regression similar to that in Mann (2018), in which each observation is a USPTO-granted patent. We focus on the Core measure, which is measured at

\footnotetext{
${ }^{15}$ In Appendix Table A.8 we show that this result is robust to using alternative years, like 2001 and 2002, as the cutoff for increased creditor rights in Chapter 11.
} 
the granting year. The outcome variable is a dummy indicating whether an individual patent is ever pledged as collateral. We find that, as hypothesized, core patents are much more likely to be used ex ante as collateral for debt financing. In fact, the economic magnitude is large - for example, in column (4), the coefficient of $I$ (Core) suggests that core patents are 19.7 percentage points more likely to be pledged as collateral, which is a $61.4 \%$ increase of the unconditional probability that a patent is used as collateral (32.1\%). We also show that patents of higher quality and patents that are more redeployable to other users are more likely to be collateralized, in line with several recent studies (Hochberg, Serrano, and Ziedonis, 2018; Mann, 2018). This pattern not only holds in bankrupt firms but also holds in the broader sample of all firms (see Table A.9 in the Online Appendix).

\section{[Insert Table 5 Here.]}

Second, we examine whether secured creditors enforce their rights specifically on the pledged patent collateral. We construct a sample at the patent-year level of all patents owned by a firm that eventually filed for Chapter 11 bankruptcy. We investigate whether, during the bankruptcy reorganization process, the collateralized innovation is more likely to be sold. We regress an indicator that a patent is sold in the year on whether the patent is collateralized $(I($ Collateralized $))$, whether the owning firm is going through bankruptcy reorganization in that year (I (In Bankruptcy) ), and the interaction of the terms.

Table 5 Panel B presents the results. In column (1), the negative coefficient for $I($ Collateralized $)$ shows that collateralized patents are not more likely to be sold outside bankruptcy. This is sensible since - as shown in Panel A - collateralized patents are often core assets of the firm. The key term, I(Collateralized $) \times I($ In Bankruptcy $)$, carries a positive coefficient, showing that collateralized patents are 7.1 percentage points more likely to be sold in bankruptcy than outside bankruptcy. Column (2) shows similar results. The evidence is consistent with the fact that lenders' foreclosure rights are only exercised upon payment defaults, which are triggered by the bankruptcy filing.

In columns (3) and (4), we add interaction terms of core and the dummy indicating bankruptcy together with the core measure. We confirm that core patents themselves are not more likely to be sold in bankruptcy. Even when the interaction term is significant 
(column 4), the economic magnitude is much smaller compared to that associated with $I($ Collateralized $) \times I($ In Bankruptcy $)$. This suggests that enforcing collateral is a key driver behind patent sales.

Finally, we confirm that sales of collateralized patents concentrate in bankrupt firms that use more secured debt. In Table 5 Panel C, we use the sample of patents owned by bankrupt firms and follow the design and measurements of Table 4. We show that collateralized patents are indeed more likely to be sold, particularly in firms with an above-median secured debt ratio. Combining this evidence with the fact that core patents are ex ante more likely to be used as collateral, our results show that the secured creditors' objective to recover their claims together with their rights prompt the bankrupt firm to sell collateralized and yet strategically important patents.

\subsubsection{Mechanism from Contracting 2: Creditor Recontracting}

The second mechanism that we consider is DIP financing through which prepetition lenders and the debtor recontract in order to finance the bankruptcy process. One notable feature of these new debt contracts is that they contain many restrictive covenants and milestones that grant significant control rights to secured lenders (Skeel, 2004; Eckbo, Li, and Wang, 2020; Ayotte and Elias, 2021). Particularly, prepayment clauses and asset sale conditions would require the debtor to conduct $\S 363$ sales and use the proceeds to pay prepetition debt. Some DIP contracts, in fact, even allow lenders to play a direct role in asset sales through milestones requiring the debtor to set up an asset bidding procedure for $\S 363$ sales. In essence, the DIP financing contract helps reinforce creditor rights. Therefore, we expect that the relation between the use of secured debt and the sale of core patents is stronger when there is DIP financing in place. ${ }^{16}$

\section{[Insert Table 6 Here.]}

Table 6 presents the results of two specifications in which we interact a dummy variable indicating whether the bankrupt firm received DIP financing with core and the secured debt ratio (as used in Table 4). We find that the triple interaction term is highly significant,

\footnotetext{
${ }^{16}$ One caveat is that the presence of DIP financing could be endogenously determined.
} 
both statistically and economically, in explaining the selling of core patents. The estimates in column (2) show that firms with high secured debt have a 10 percentage points higher probability in selling core patents when there is DIP financing than without. In fact, the power of this re-contracting mechanism is so strong that the interaction term of Core and High secured debt ratio is not statistically significant. Interestingly, the results also show that low-secured-debt firms with DIP financing are not more likely to sell core patents than those without DIP financing. The evidence suggests that DIP financing enables secured creditors to strongly enforce their rights in bankruptcy.

\subsection{Creditors' Incentives}

The effect of secured debt on patent sales is governed by both the rights provided by the financial contracts and the incentives of creditors in exercising such rights. According to the Bankruptcy Code, if secured creditors' claims are under-collateralized, they are not entitled to "adequate protection" and a fraction of the debt would be considered an unsecured deficiency claim. In such cases, secured debt is likely to become the "fulcrum" class (i.e., the class of debt that is most likely not recovered in full and that will be compensated with new equity of the reorganized firm). As a result, secured creditors' incentives are more aligned with those of unsecured creditors, and the selling of core patents should be less observed in such cases.

This section investigates how the pattern of patent sale varies by secured creditors' incentives. We adopt two sets of measures to gauge whether secured creditors' claims are likely the fulcrum class. The first set of measures is based on the ex post recovery rate of secured debt and the distribution method, which are collected from reorganization plans and disclosure statements that are confirmed by the court. We treat secured debt as the fulcrum class if secured creditors do not receive full recovery (Fulcrum $(<100 \%$ Recovery)) or if they are compensated with new equity of the reorganized firm (Fulcrum (Loan-to-Own)).

Our second measure is based on the level of collateralization of secured debt. As suggested by Ayotte and Morrison (2009), secured creditors' incentives to enforce sales of collateralized patents depend on the extent of debt collateralization. When secured debts are undercollateralized (so they likely become residual claims of the reorganized entity), their payoffs vary with the firm value as a whole rather than the value of the collateral itself. We use 
the ratio of secured debt to the book assets as a proxy for the level of collateralization. We construct an indicator variable Under-collateralized that takes on the value of one if a firm's secured debt amount is larger than book assets, i.e., under-collateralized. ${ }^{17}$

Table 7 examines the innovation selling pattern of bankrupt firms by whether secured creditors are likely the fulcrum class. In column (1), we find that core patents are more likely to be sold in bankruptcy, but this pattern is significantly mitigated in the sample of cases in which the ex post recovery rates are below 100\%, as captured by the interaction term between core and the dummy variable indicating less-than-full recovery. Similarly, we find that the activity of selling off core patents is mitigated in loan-to-own cases (column (2)) and when the secured creditors are under-collateralized (column (3)). ${ }^{18}$

\section{[Insert Table 7 Here.]}

In column (4), we investigate another set of bankruptcy cases in which all creditor classes agree to a reorganization plan before bankruptcy filing - the prepackaged deals, whereby the interests of different classes of creditors are more aligned in maximizing the value of the firm as a whole. We show that the probability of a core patent being sold is lower in prepackaged deals. In fact, the combined effect of core and its interaction with the prepack dummy is so strong that in such deals, firms are effectively selling non-core patents as firms do outside bankruptcy. ${ }^{19}$

Secured creditors' incentives and ability to recover via selling core patents may have implications for their own recovery and the welfare of junior creditors. In Appendix Table

\footnotetext{
${ }^{17}$ As a caveat, our results should be interpreted with caution, as a secured debt's lien is not always on all assets of the debtor firm. Note that the pairwise correlation between Secured Debt Ratio and Secured Debt/Assets is not high (0.33) as the first measure captures the use of secured debt in a firm's debt structure and the other proxies for collateralization of secured debt.

${ }^{18}$ We have non-missing secured debt recovery information for 117 firms and non-missing information on the method of distributions for 179 firms in our sample due to the limited availability of reorganization/liquidation plans and disclosure statements. The fraction of cases that are defined as fulcrum based on the three measures are $38.5 \%, 27.9 \%$, and $5 \%$, respectively.

${ }^{19}$ In Appendix Table A.10, we perform our main specification on subsamples categorized by whether hedge funds and private equity funds are members of the unsecured creditors' committee (UCC) (Jiang, Li, and Wang, 2012; Goyal and Wang, 2017). These specialized investors are typically the new residual claimants of firm value at emergence and have both strong incentives and skills to prevent the sale of strategically important assets in bankruptcy. We find that hedge funds and private equity funds sit on the UCC in $38 \%$ of our sample firms, and the selling of core patents is stronger when no such investors are on the UCC while core patents are not more likely to be sold when such investors serve on the UCC.
} 
A.11, we show that secured creditors recover more at the end of the bankruptcy process after core patents are sold, but unsecured creditors do not recover more. More importantly, using detailed information from court dockets, we find in Appendix Table A.12 that $\S 363$ sale motions allowing the firm to sell core patents are more likely to face objections from unsecured creditors. The evidence speaks directly to the unsecured creditors' negative view on core patent sales.

\subsection{The Selection Issue of Bankrupt Firms}

It is sobering to acknowledge that bankrupt innovative firms are a selected set of firms, and the level of secured debt is indeed a firm choice. The detailed mechanisms described above mitigate part of this concern. However, one might wonder whether the selection effect may drive our results. Specifically, firms in bankruptcy may have been unproductive in their previous core business and therefore voluntarily change their lines of business - thus, selling core assets simply reflects this course-switching effort.

Even though it is far from being conclusive, we find evidence that is largely inconsistent

with this argument. First, most of the firms stay in the same industry (at the four-digit SIC level) upon emergence and keep patenting in the same key technology classes. Second, firms that suffer financial but not economic distress (empirically defined in our sample as high leverage and also high ROA) and use the bankruptcy system to resolve capital structure issues rather than change the course of operation also sell their core patents (column (7) of Table 3). Finally, our results are robust when we focus on patents that are produced more recently (column (8) of Table 3), which more likely reflect the firms' future direction of innovation.

\section{Market for Technology and Technology Diffusion}

The previous section shows that financial contracting and creditor rights have a strong influence on patent reallocation of innovative firms in bankruptcy. The findings point to an important set of new questions regarding the real impact of finance in the area of market for technology and technology diffusion - how are sold patents exploited under the new 
ownership? Who are the buyers of sold patents?

\subsection{Post-sale Citations}

We first characterize the dynamics of citations made to patents sold. Figure 4 plots the coefficients $\beta_{k}$ from the following regression at the patent $(p)$-year $(t)$ level:

$$
\text { Citation }_{p t}=\sum_{k=-3}^{+3} \beta_{k} \cdot d[t+k]_{p t}+\gamma \cdot \text { Controls }_{p t}+\alpha_{p}+\alpha_{t}+\varepsilon_{p t} .
$$

Citation $_{p t}$ is the number of new citations a patent receives in a given year. One can think of this annual citation flow as measuring the exploitation of the underlying technologies defined by the patent (Jaffe and Trajtenberg, 2002). The dummy variable $d[t+k]$ equals one if the patent observation is $k$ years from the sale of the patent, and zero otherwise. We control for patent age, measured as the logarithm of the patent age in year $t$. We also include year and patent fixed effects, $\alpha_{t}$ and $\alpha_{p}$. The $\beta$ coefficients thus capture the citation dynamics of sold patents around the transaction compared to the universe of all other patents.

Using this regression framework, we perform multiple regressions that are shown in Figure 4. Those analyses differ in two dimensions. First, we separately characterize the citation dynamics of patents sold by different firms and in different periods - sold in bankruptcy (Panel A), outside bankruptcy by non-bankrupt firms (Panel B), and by bankrupt firms but sold three years prior to bankruptcy filings (Panel C). Second, for the Citation pt $_{\text {variable }}$ for each patent-year, we perform separate estimations using the total citations received by the patent, those from the buyer, and those from the seller (i.e., the bankrupt firm itself for in-bankruptcy sales).

\section{[Insert Figure 4 Here.]}

Several interesting findings emerge. First, the overall utilization of the patents sold during the bankruptcy process experiences an "up then down" dynamic (A1). In contrast, for sales that happen out of bankruptcy, patent citations experience a clear increase post sales following a decline beforehand, i.e., "down then up" (B1). The magnitude is economically meaningful. In A1, the -0.075 at $[t+3]$ translates to a $14 \%$ decrease of annual citations. The 
pattern suggests that for those sales outside bankruptcy, patents are typically better matched to the buyer and thus are better exploited (see B2 for buyer citations), consistent with the argument in Akcigit, Celik, and Greenwood (2016). Bankrupt firms, on the other hand, sell better-utilized hot patents (the "up" part), yet they fall in total citations afterward (the "down" part).

Second, the number of citations made by the bankrupt firm remains flat prior to and subsequent to patent sales in bankruptcy - the post-sale usage pattern is statistically indistinguishable from that prior to the sale. Out-of-bankruptcy sales feature a sharp decline in internal usage before sale (B3), which partially contributes to the pre-sale decline of total citations in B1. The evidence suggests that the firms sell under-exploited patents out of bankruptcy.

In our preferred interpretation, the post-sale citation dynamics suggest that out of bankruptcy, firms sell under-exploited patents and the patents appear to be better exploited post sale. In-bankruptcy sales, however, feature the transfer of better-used patents that ex post become less impactful in the hands of the new owners - potentially due to lack of commercialization or continued successful development of the acquired technology.

However, we would like to cautiously note that the analysis does not have the luxury of having a clean counter-factual. As a result, we cannot conclusively exclude certain alternative explanations. Most noticeably, bankrupt firms' patents may be of lower value or on a natural downward trend; or they intentionally select fading technologies to sell. We share this concern and use Panel $\mathrm{C}$ to analyze an alternative benchmark-bankrupt firms themselves, but three years prior to bankruptcy. Across all three measures of citations, the patterns are very close, both qualitatively and quantitatively, to those shown in Panel B.

Overall, the evidence suggests that the functioning of the financial market not only affects the production of innovation (Kerr and Nanda, 2015), but also the exploitation and diffusion of innovation. Patents sold during different financial conditions appear to have different paths of future exploitation and diffusion. 


\subsection{Patent Troll Purchases and Patent Litigation}

We next examine the types of buyers of the patents sold in bankruptcy, with a specific focus on the role of patent trolls. Patent trolls are becoming an important concern for innovation (Cohen, Gurun, and Kominers, 2016). They purchase patents with the purpose of bringing lawsuits against cash-rich innovative firms, and they do so in an opportunistic manner. If the reallocation of patents in bankruptcy is mainly for the redeployment of technologies, those patents should be sold to the potential users of the technologies, i.e., the practicing entities. If, however, the sale of core innovation is a result of creditors' push for a quick sale of collateral, opportunistic patent trolls can be more active buyers in this process.

We start by investigating whether patents sold in bankruptcy are more likely to be sold to a patent troll. We construct a cross-sectional data set of all patent transactions between 1981 and 2015, and we regress the indicator of whether a patent is sold to a patent troll on the dummy of whether the sale happens in bankruptcy, where the patent troll indicator is obtained from Akcigit, Celik, and Greenwood (2016) and Cohen, Gurun, and Kominers (2019). The results are shown in Table 8 Panel A. We find that patents sold in bankruptcy are more likely to go to a patent troll. In terms of economic magnitude, the 0.020 in column (4) means that in-bankruptcy sales are $200 \%$ more likely to be sold to a non-practicing entity than are out-of-bankruptcy sales (baseline rate of patent troll purchases is 1\%).

There is another way to assess the importance of the trading flow from industrial firms to NPEs that is prompted by the bankruptcy. Patent trolls are becoming a social concern, and the activities of NPEs are fueled by patents available to them. We investigate the proportion of patents acquired and possessed by NPEs that are purchased during the bankruptcy. We find that $12 \%$ of the patents owned by our identified NPEs as of 2015 are acquired from the bankruptcy process of the public firms in our sample. Quite interestingly, this ratio is heavily driven by above-median NPE-owned patents. Among the above-median-citation patents (based on patent citations), owned by NPEs, 17\% are acquired during an industrial firm's bankruptcy. This means that NPEs take the bankruptcy opportunity to acquire better patents that are otherwise difficult to obtain.

[Insert Table 8 Here.] 
Since patent trolls focus on the promise of litigating using patents rather than exploiting the technologies, we would see that core patents in categories with high litigation risk are more likely to be bought. To capture a patent's litigation risk, we obtain data from Lex Machina, Derwent LitAlert, and the RPX database. We calculate the litigation risk of each technology class as the ratio of litigated patents over the total number of patents in the technology class. Table 8 Panel B presents the results, structured similarly as above, showing that the pattern of selling core innovation is associated with the potential of litigating using purchased patents. Even though patent litigation is uncommon in our sample (1\% of patents are in litigation), it has strong explanatory power in patent allocation in bankruptcy. Overall, this evidence shows that patents sold in bankruptcy are more likely to go to patent trolls for litigation reasons than to be used in productive exploitation. ${ }^{20}$

\section{Concluding Remarks}

This paper provides a comprehensive study on bankrupt innovative firms that seek "a fresh start" using Chapter 11. Those firms sell, almost immediately, their core innovation (i.e., technologically critical to the business) instead of peripheral innovation. They sell off their core innovation due to creditor rights through the collateral mechanism. We also document the consequences of such patent reallocations to technology diffusion.

The findings have several implications that may be worth highlighting. First, in the recent debate over bankruptcy reform (such as that from the American Bankruptcy Institute Commission to Study the Reform of Chapter 11 in 2015), for a knowledge-based economy, it is important to consider the impact of the bankruptcy institution on innovation allocation and technology diffusion. Second, from a firm's perspective, financial contracting with lenders should factor in the ex post consequence to innovation. Third, this paper raises, but does not

\footnotetext{
${ }^{20}$ In a separate analysis, we exploit our sample of $518 \S 363$ asset sales to examine the occurrence of creditor bidding in patent sales in bankruptcy. For each sale motion, we search for whether Section 363(k) is mentioned and determine whether creditors are allowed to participate or actually participated in bidding. After identifying both stalking-horse bidders and the final wining bidders, we find that credit bidding for patents is rather rare. A credit bid occurs in only $2.1 \%$ of total sale transactions and $3.4 \%$ of transactions with a stalking horse. The low frequency of credit bidding is consistent with prior evidence on general asset sales (Gilson, Hotchkiss, and Osborn, 2016). Compared to real assets, intellectual properties are even less likely to receive a credit bid due to the nature of these assets such as their option-like features and that trading IP requires expertise.
} 
fully answer, the question of how to efficiently redeploy and aggregate innovation from firms that go bust. 


\section{References}

Acharya, V. V., and K. V. Subramanian. 2009. Bankruptcy codes and innovation. Review of Financial Studies 4949-88.

Akcigit, U., M. A. Celik, and J. Greenwood. 2016. Buy, keep, or sell: Economic growth and the market for ideas. Econometrica 84:943-84. ISSN 1468-0262. doi:10.3982/ECTA12144.

Andrade, G., and S. N. Kaplan. 1998. How costly is financial (not economic) distress? evidence from highly leveraged transactions that became distressed. Journal of Finance 53:1443-93.

Arora, A., A. Fosfuri, and A. Gambardella. 2004. Markets for technology: The economics of innovation and corporate strategy. MIT press.

Asquith, P., R. Gertner, and D. Scharfstein. 1994. Anatomy of financial distress: An examination of junk-bond issuers. Quarterly Journal of Economics 109:625-58. ISSN 0033-5533.

Ayotte, K., and J. A. Elias. 2021. Bankruptcy process for sale. Yale Journal on Regulation Forthcoming.

Ayotte, K., and D. A. Skeel. 2013. Bankruptcy law as a liquidity provider. The University of Chicago Law Review 1557-624.

Ayotte, K. M., and E. R. Morrison. 2009. Creditor control and conflict in chapter 11. Journal of Legal Analysis 1:511-51.

Baird, D. G., and B. Rasmussen. 2002. The end of bankruptcy. Stanford Law Review 55.

Benmelech, E., and N. K. Bergman. 2011. Bankruptcy and the collateral channel. Journal of Finance 66:337-78.

Benmelech, E., N. Kumar, and R. Rajan. 2020. The decline of secured debt. Working paper .

Bernstein, S., E. Colonnelli, X. Giroud, and B. Iverson. 2019. Bankruptcy spillovers. Journal of Financial Economics 133:608-33.

Bernstein, S., E. Colonnelli, and B. Iverson. 2019. Asset reallocation in bankruptcy. Journal of Finance 74:5-53.

Bharath, S., V. Panchapagesan, and I. Werner. 2014. The changing nature of chapter 11. Working Paper.

Brav, A., W. Jiang, S. Ma, and X. Tian. 2018. How does hedge fund activism reshape corporate innovation? Journal of Financial Economics 130:237-64. ISSN 0304-405X. doi:https://doi.org/10.1016/j.jfineco.2018.06.012. 
Brown, J. R., S. M. Fazzari, and B. C. Petersen. 2009. Financing innovation and growth: Cash flow, external equity, and the 1990s R\&D boom. Journal of Finance 64:151-85. ISSN $1540-6261$.

Carey, M., and M. B. Gordy. 2016. The bank as grim reaper: Debt composition and bankruptcy thresholds. Journal of Financial Economics forthcoming.

Chava, S., V. Nanda, and S. C. Xiao. 2017. Lending to innovative firms. The Review of Corporate Finance Studies 6:234-89.

Cohen, L., U. G. Gurun, and S. D. Kominers. 2016. The growing problem of patent trolling. Science 352:521-2.

—. 2019. Patent trolls: Evidence from targeted firms. Management Science 65.

Colla, P., F. Ippolito, and K. Li. 2013. Debt specialization. Journal of Finance 68:2117-41.

Eckbo, B. E., K. Li, and W. Wang. 2020. Rent extraction by super-priority lenders. Working paper.

Ederer, F., and G. Manso. 2011. Incentives for innovation: Bankruptcy, corporate governance, and compensation systems. Handbook of Law, Innovation, and Growth 90-111.

Figueroa, N., and C. J. Serrano. 2019. Patent trading flows of small and large firms. Research Policy 48:1601-16.

Gans, J., and S. Stern. 2010. Is there a market for ideas? Industrial and Corporate Change 19:805-37.

Gilson, S. C., E. S. Hotchkiss, and M. G. Osborn. 2016. Cashing out: The rise of $\mathrm{m} \& \mathrm{a}$ in bankruptcy. Available at SSRN 2547168 .

Goyal, V., and W. Wang. 2017. Provision of management incentives in bankrupt firms. Journal of Law, Finance, and Accounting 2.

Graham, S. J., A. C. Marco, and A. F. Myers. 2018. Lessons from the uspto patent assignment dataset. Journal of Economics and Management Strategy 27:343-71.

Hall, B. H., and J. Lerner. 2010. The financing of $r \& d$ and innovation. Handbook of the Economics of Innovation 1:609-39. ISSN 2210-8807.

Hochberg, Y. V., C. J. Serrano, and R. H. Ziedonis. 2018. Patent collateral, investor commitment, and the market for venture lending. Journal of Financial Economics 130:7494.

Jaffe, A. B., and M. Trajtenberg. 2002. Patents, citations, and innovations: A window on the knowledge economy. MIT Press: Cambridge, MA.

Jiang, W., K. Li, and W. Wang. 2012. Hedge funds and chapter 11. Journal of Finance 67:513-60. 
Kerr, W. R., and R. Nanda. 2015. Financing innovation. Annual Review of Financial Economics 7:445-62.

Li, K., and W. Wang. 2016. Debtor-in-possession financing, loan-to-loan, and loan-to-own. Journal of Corporate Finance 39:121-38.

Ma, S. 2020. The life cycle of corporate venture capital. Review of Financial Studies 33:358-94.

Maksimovic, V., and G. Phillips. 1998. Asset efficiency and reallocation decisions of bankrupt firms. Journal of Finance 53:1495-532.

Mann, W. 2018. Creditor rights and innovation: Evidence from patent collateral. Journal of Financial Economics 130:25-47.

Meier, J.-M. A., and H. Servaes. 2019. The bright side of fire sales. Review of Financial Studies 32:4228-70.

Nini, G., D. C. Smith, and A. Sufi. 2009. Creditor control rights and firm investment policy. Journal of Financial Economics 92:400-20.

- 2012. Creditor control rights, corporate governance, and firm value. Review of Financial Studies 25:1713-61.

Pulvino, T. C. 1999. Effects of bankruptcy court protection on asset sales. Journal of Financial Economics 52:151-86.

Ramey, V. A., and M. D. Shapiro. 2001. Displaced capital: A study of aerospace plant closings. Journal of Political Economy 109:958-92.

Roberts, M. R., and A. Sufi. 2009a. Control rights and capital structure. Journal of Finance 64:1657-95.

. 2009b. Financial contracting: A survey of empirical research and future directions. Annual Review of Financial Economics 1:207-26.

Serrano, C. J. 2010. The dynamics of the transfer and renewal of patents. RAND Journal of Economics 41:686-708.

Skeel, D. A. 2004. The past, present, and future of debtor-in-possession financing. Cardozo Law Review 1905-34. 

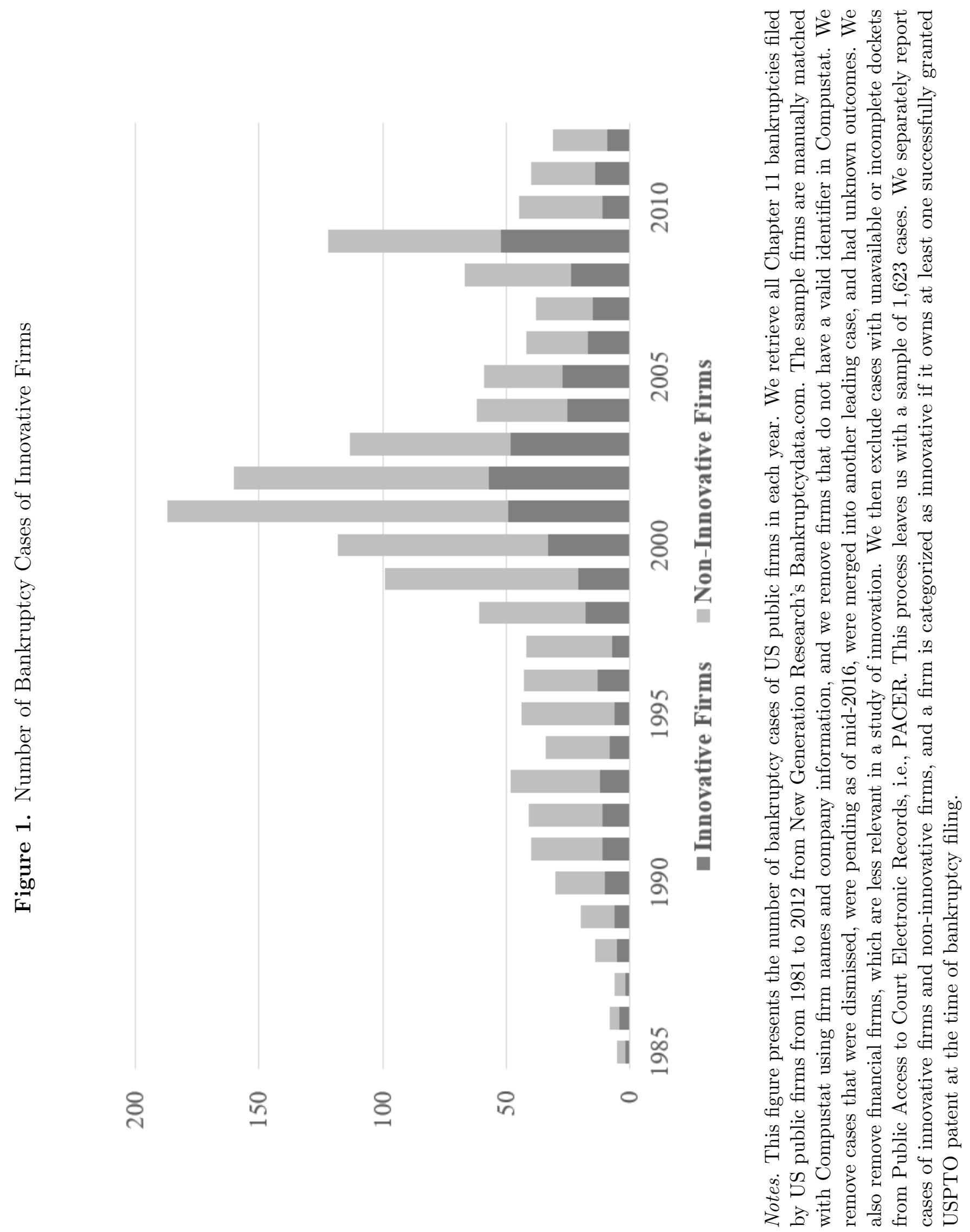

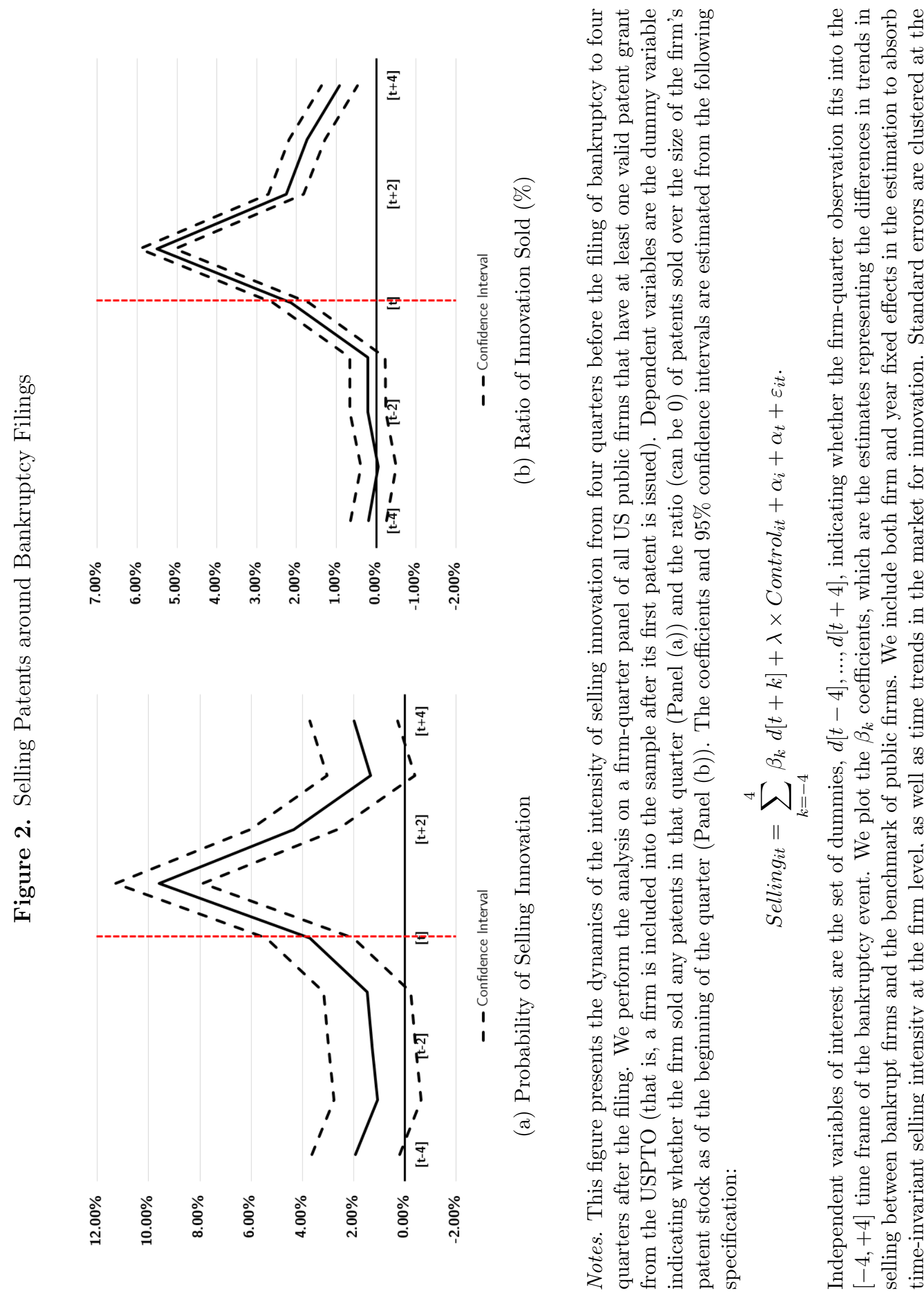

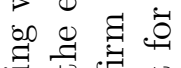

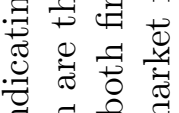
궝영

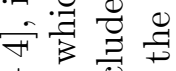
+ का. I 荡造

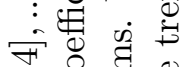
1 ठ है $\frac{\omega}{\sigma} \frac{0}{0}$ क्षे है 当

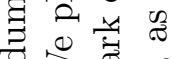
㻤急

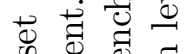
๑ ठ

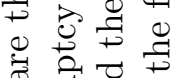
司㐘

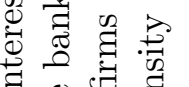
寻总范苛 可 营 $>$ \&

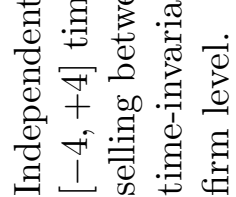



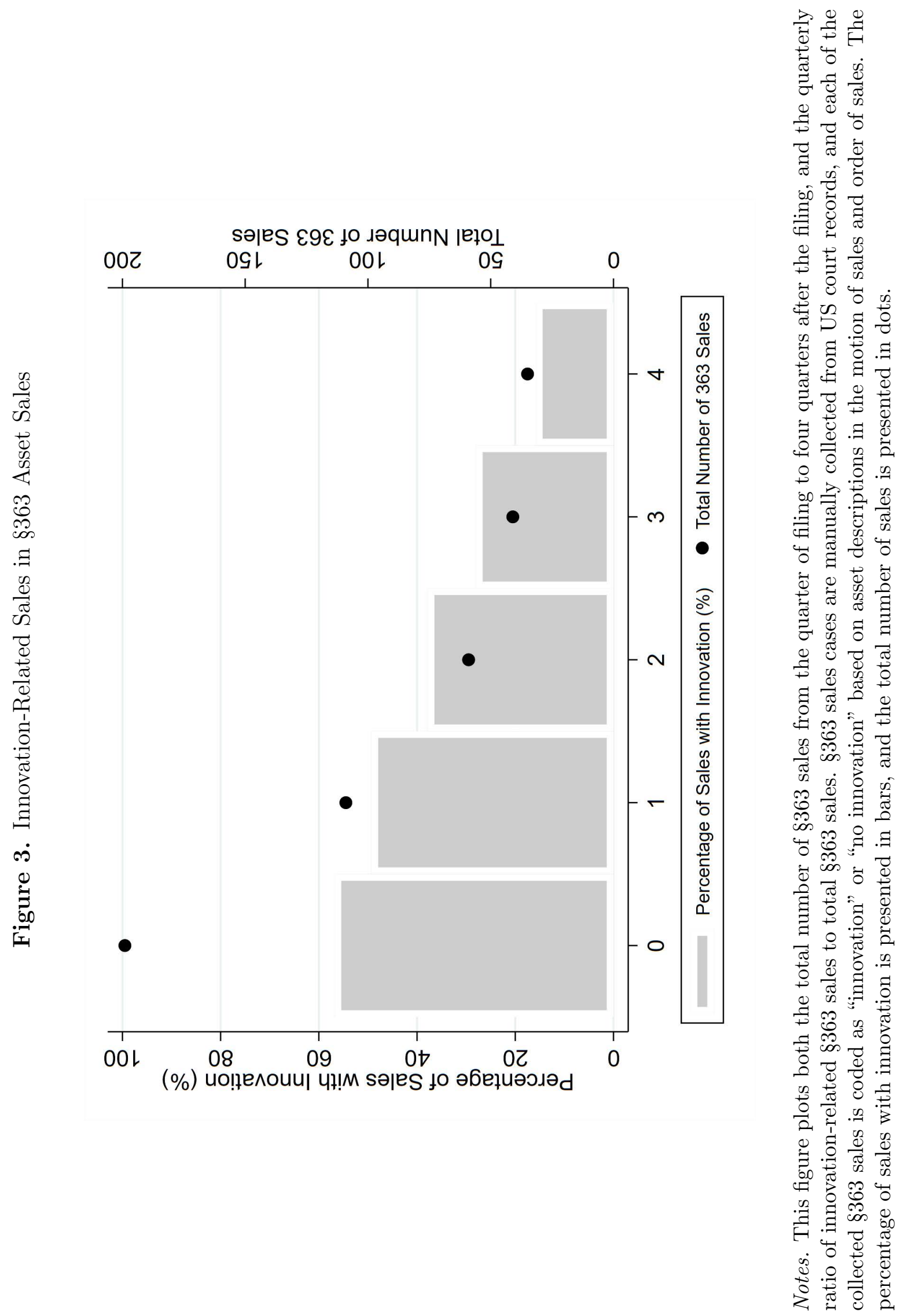

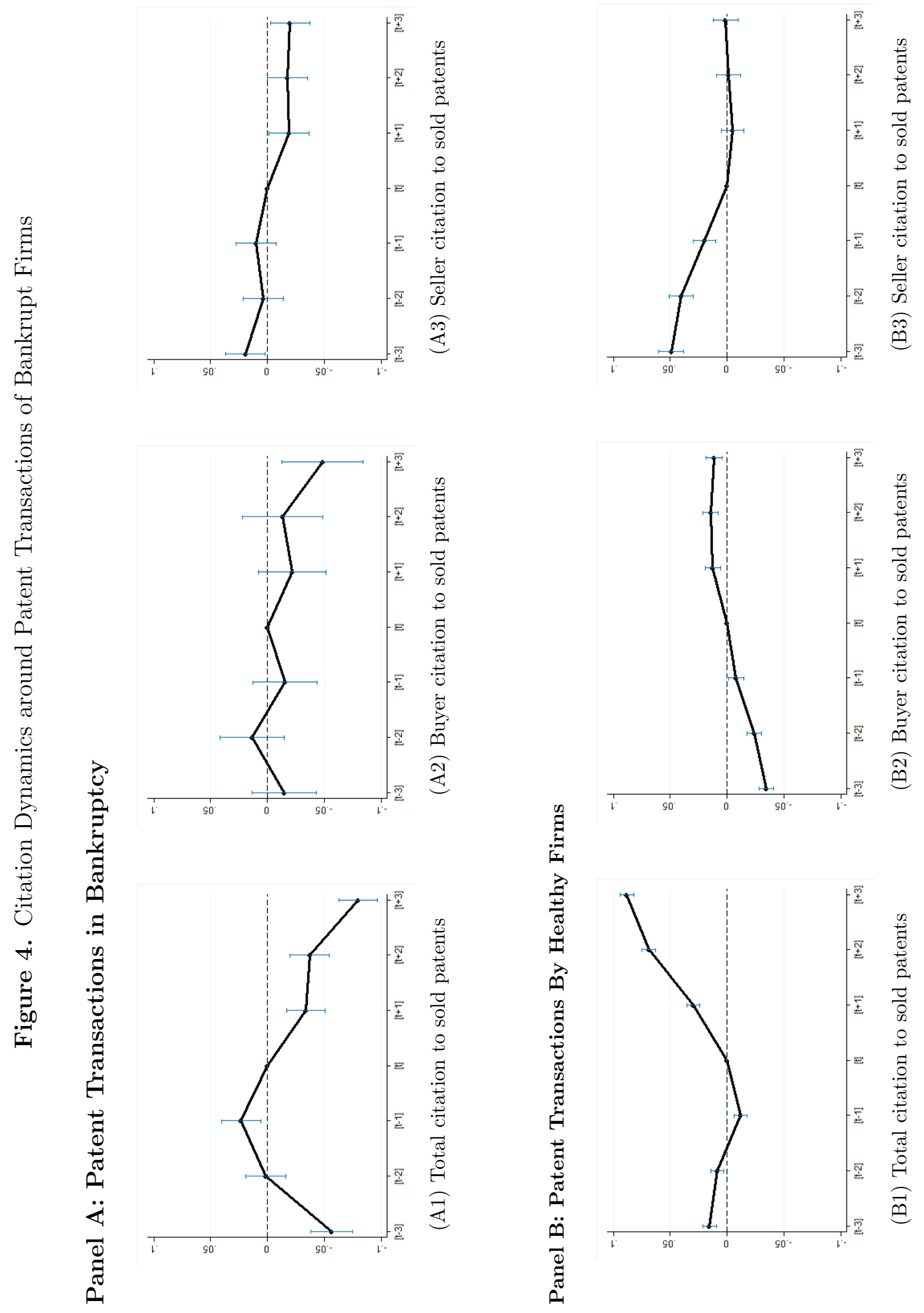

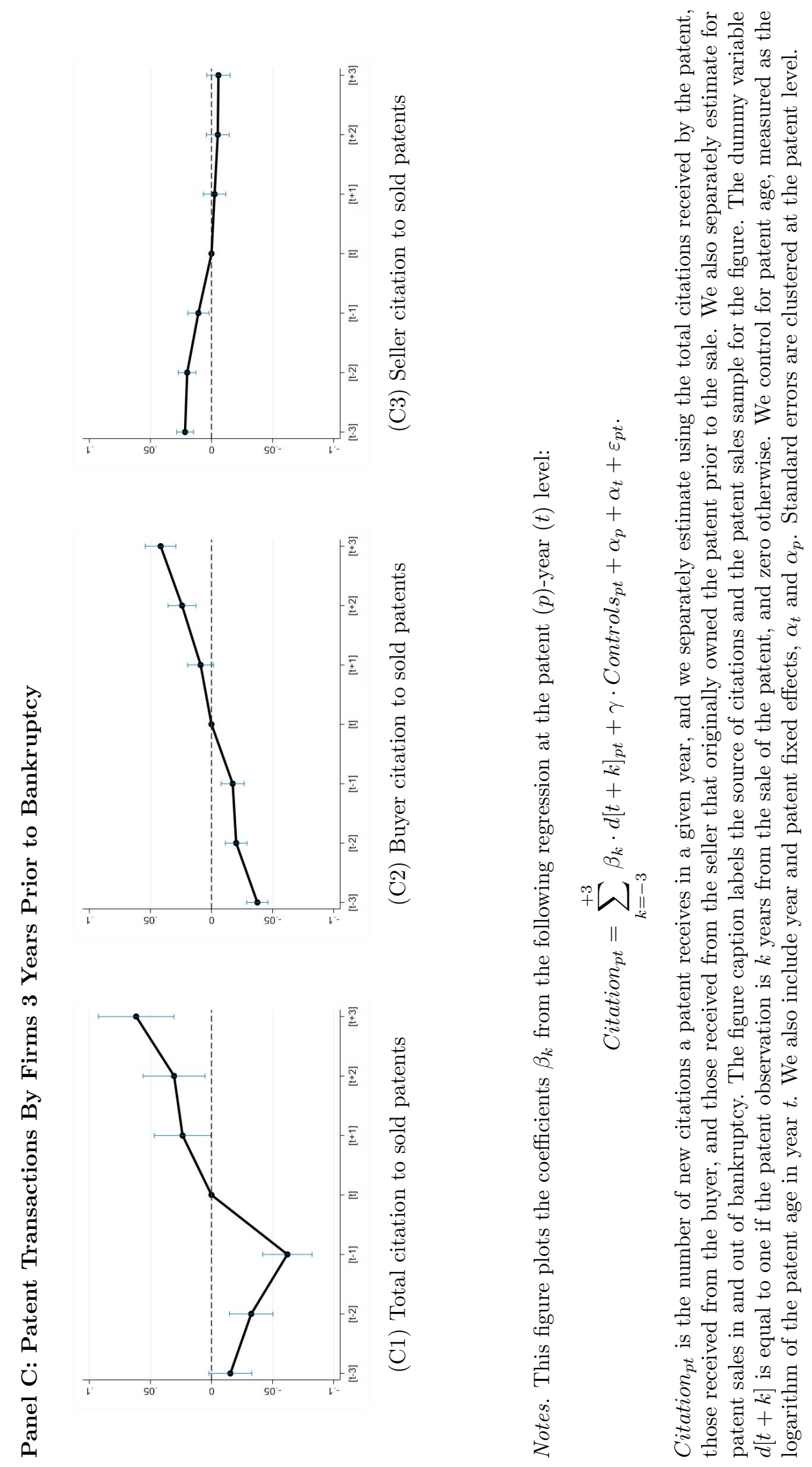
Table 1. Overview of Bankrupt Firms and Innovation Transactions

Panel A: Bankruptcy Cases and Patent Transactions by Fama-French 12 Industries

\begin{tabular}{lcccc}
\hline & \multicolumn{2}{c}{ Number of Observations } & \multicolumn{2}{c}{$\begin{array}{c}\text { Selling [Filing, Confirmation] } \\
\text { \% of Firms }\end{array}$} \\
\cline { 2 - 5 } Coll Sample & Innovative Sample & oftents \\
\cline { 2 - 5 } Consumer Non-durables & 132 & 49 & $29 \%$ & $18 \%$ \\
Consumer Durables & 77 & 44 & $52 \%$ & $11 \%$ \\
Manufacturing & 192 & 117 & $33 \%$ & $10 \%$ \\
Oil & 68 & 5 & $40 \%$ & $40 \%$ \\
Chemicals & 36 & 16 & $38 \%$ & $6 \%$ \\
Business Equipment & 231 & 127 & $46 \%$ & $24 \%$ \\
Telecommunication & 126 & 16 & $38 \%$ & $31 \%$ \\
Utilities & 24 & 9 & $44 \%$ & $24 \%$ \\
Wholesale and Retail & 305 & 33 & $24 \%$ & $15 \%$ \\
Health care & 127 & 48 & $56 \%$ & $29 \%$ \\
Other Industries & 305 & 54 & $35 \%$ & $15 \%$ \\
\hline Total & 1,623 & 518 & $40 \%$ & $18 \%$ \\
\hline
\end{tabular}


Panel B: Bankruptcy Cases and Patent Transactions by Filing Year

\begin{tabular}{lcccc}
\hline & \multicolumn{2}{c}{ Number of Observations } & \multicolumn{2}{c}{$\begin{array}{c}\text { Selling } \\
\text { \% Filing, Confirmation] }\end{array}$} \\
\cline { 2 - 5 } 1981 & Full Sample & Innovative Sample & of Firms & \% of Patents \\
\cline { 2 - 4 } 1982 & 3 & 0 & - & - \\
1983 & 1 & 1 & $0 \%$ & $0 \%$ \\
1984 & 0 & 0 & - & - \\
1985 & 5 & 0 & - & - \\
1986 & 8 & 2 & $0 \%$ & $0 \%$ \\
1987 & 6 & 4 & $50 \%$ & $17 \%$ \\
1988 & 14 & 2 & $100 \%$ & $29 \%$ \\
1989 & 20 & 5 & $20 \%$ & $10 \%$ \\
1990 & 30 & 6 & $50 \%$ & $21 \%$ \\
1991 & 40 & 10 & $20 \%$ & $10 \%$ \\
1992 & 41 & 11 & $18 \%$ & $9 \%$ \\
1993 & 48 & 11 & $18 \%$ & $1 \%$ \\
1994 & 34 & 12 & $33 \%$ & $5 \%$ \\
1995 & 44 & 8 & $38 \%$ & $26 \%$ \\
1996 & 43 & 6 & $67 \%$ & $20 \%$ \\
1997 & 42 & 13 & $31 \%$ & $14 \%$ \\
1998 & 61 & 7 & $57 \%$ & $36 \%$ \\
1999 & 99 & 18 & $33 \%$ & $20 \%$ \\
2000 & 118 & 21 & $48 \%$ & $21 \%$ \\
2001 & 187 & 33 & $52 \%$ & $23 \%$ \\
2002 & 160 & 49 & $45 \%$ & $22 \%$ \\
2003 & 113 & 57 & $39 \%$ & $21 \%$ \\
2004 & 62 & 48 & $44 \%$ & $22 \%$ \\
2005 & 59 & 25 & $32 \%$ & $15 \%$ \\
2006 & 42 & 27 & $44 \%$ & $15 \%$ \\
2007 & 38 & 17 & $47 \%$ & $15 \%$ \\
2008 & 67 & 15 & $27 \%$ & $17 \%$ \\
2009 & 122 & 24 & $25 \%$ & $15 \%$ \\
2010 & 45 & 52 & $50 \%$ & $16 \%$ \\
2011 & 40 & 11 & $18 \%$ & $12 \%$ \\
2012 & 31 & 14 & $14 \%$ & $10 \%$ \\
\hline Total & 1,623 & 9 & $67 \%$ & $43 \%$ \\
\hline & & 518 & $40 \%$ & $18 \%$ \\
\hline
\end{tabular}

Notes. This table provides an overview of the sample of bankrupt firms and their innovation (patent)-selling activities during the bankruptcy reorganization process. The sample is tabulated by the Fama-French 12 industry classification (Panel A) and by year (Panel B). The sample covers all Chapter 11 bankruptcies filed by US public companies from 1981 to 2012, resolved as of mid-2016, and is manually matched with Compustat. We remove cases of financial corporations. Financial, operation, and case information is collected from Compustat/CRSP, Capital IQ, case petitions and PACER. The patent-holding information of each firm from 1976 to 2006 is accessed using the NBER patent database; we extend that database to 2012 using Bhaven Sampat's USPTO patent and citation data. Patent transactions are obtained from the USPTO patent reassignment database from 1976 to 2015.

In each panel, we report the number of bankrupt firms in each industry/year and the number of innovative firms (defined as those owning at least one patent at the time of bankruptcy filing). We report the proportion of firms that sold at least one patent during bankruptcy periods, and the ratio of patents that were sold (the ratio of sold patents is defined as zero for firms that sold no patents). Patent-selling activities are reported for the bankruptcy reorganization process - that is, between the bankruptcy filing date and the confirmation date of the reorganizing plan. 
Table 2. Summary of Bankrupt Firms and Their Patents

Panel A: Summary Statistics of Patents Owned by Bankrupt Firms

\begin{tabular}{lccccc}
\hline & \multicolumn{5}{c}{ Patents $(\mathrm{N}=62,770)$} \\
Sold & Mean & Std.Dev & $\mathrm{p} 25$ & $\mathrm{p} 50$ & $\mathrm{p} 75$ \\
\cline { 2 - 6 } Core $(\iota=0.66)$ & 0.083 & 0.276 & 0 & 0 & 0 \\
$\mathrm{I}($ Core $)$ & 0.444 & 0.274 & 0.213 & 0.377 & 0.673 \\
Core $\iota=0.33)$ & 0.245 & 0.430 & 0 & 0 & 0 \\
Collateral & 0.572 & 0.306 & 0.316 & 0.555 & 0.863 \\
Scaled Citations & 0.321 & 0.467 & 0 & 0 & 1 \\
I(Young Patent) & 1.075 & 1.835 & 0.226 & 0.632 & 1.339 \\
Redeployability & 0.254 & 0.435 & 0 & 0 & 1 \\
MFT Liquidity & 0.789 & 0.327 & 0.667 & 1.000 & 1.000 \\
& 0.033 & 0.022 & 0.021 & 0.030 & 0.039 \\
\hline
\end{tabular}

Panel B: Summary Statistics of Bankrupt Innovative Firms (Cases)

\begin{tabular}{lccccc}
\hline & \multicolumn{5}{c}{ Number of Cases $(\mathrm{N}=518)$} \\
& Mean & Std.Dev & $\mathrm{p} 25$ & $\mathrm{p} 50$ & $\mathrm{p} 75$ \\
\cline { 2 - 6 } Prepack & 0.089 & 0.285 & 0 & 0 & 0 \\
Duration (in days) & 510.772 & 537.909 & 203 & 369 & 641 \\
Outcome (Acquired) & 0.127 & 0.334 & 0 & 0 & 0 \\
Outcome (Converted) & 0.122 & 0.327 & 0 & 0 & 0 \\
Outcome (Emerged) & 0.512 & 0.500 & 0 & 1 & 1 \\
Outcome (Liquidated) & 0.239 & 0.427 & 0 & 0 & 0 \\
& & & & & \\
Assets & & & & & \\
ROA & 972.825 & 5569.812 & 23.160 & 93.974 & 302.130 \\
R\&D/Assets & -0.294 & 0.530 & -0.412 & -0.140 & 0.004 \\
Patent Stock & 0.114 & 0.201 & 0.004 & 0.028 & 0.133 \\
Secured Debt Ratio & 175.145 & 1284.467 & 3 & 13 & 39 \\
\hline
\end{tabular}

Notes. This table reports summary statistics of bankrupt firms and their patents owned at the time of filing bankruptcy. The sample covers all Chapter 11 bankruptcies filed by US public companies from 1981 to 2012, resolved as of mid-2016, and is manually matched with Compustat. We remove cases of financial corporations. The patent-holding information of each firm from 1976 to 2006 is accessed using the NBER patent database; we extend that database to 2012 using Bhaven Sampat's USPTO patent and citation data. Patent transactions are obtained from the USPTO patent reassignment database from 1976 to 2015.

Panel A reports patent-level information. Panel B reports firm-level information collected from case petitions, Compustat/CRSP, Capital IQ, and PACER. Detailed variable definitions can be found in Section 2 of the paper and the Appendix. The variable values are measured as of the year before bankruptcy filing. For each variable, we report the mean, standard deviation, and 25th, 50th, and 75th percentiles. 


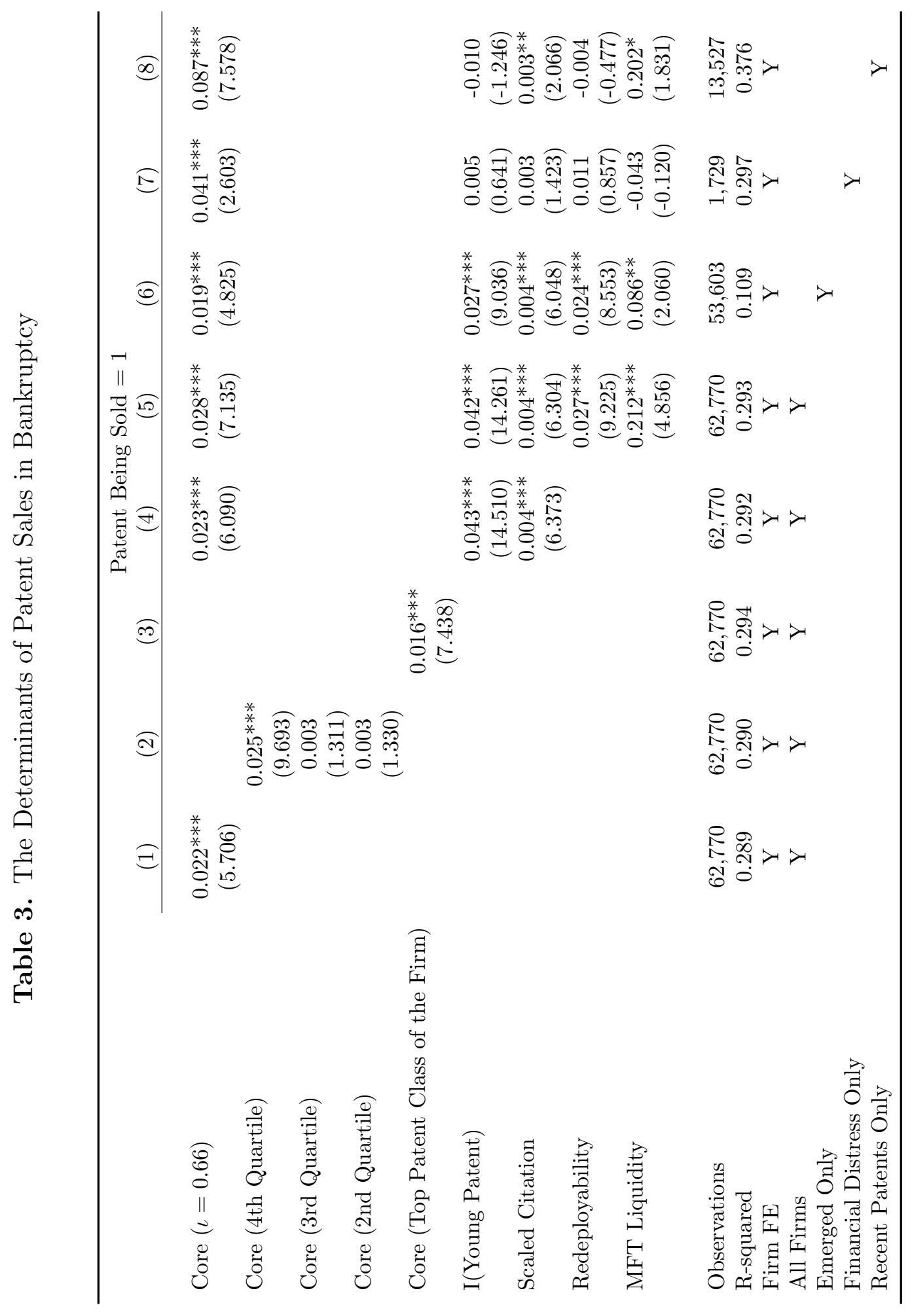


Notes. This table presents how innovation reallocation in bankruptcy is affected by patent-level characteristics. The analysis is conducted on a patent-level data set, and each observation is a patent $p$ in a bankrupt firm $i$ 's patent portfolio in the year of bankruptcy filing, using the following model:

$$
\text { Sold }_{i p}=\beta \cdot \text { Core }_{i p}+\lambda \times \text { Control }_{i p}+\alpha_{i}+\varepsilon_{i p} .
$$

The dependent variable $S_{\text {old }}$ ip is a dummy variable indicating whether patent $p$ is sold during the bankruptcy reorganization process (from bankruptcy filing to the confirmation of the reorganization plan) by its owning firm $i$. Core is the distance between the patent and the firm's core technological expertise as defined in Section 2, with parameters $\iota=0.66$. Core is also discreted into within-firm quartiles and Core(Quartile) are dummy variables indicating the quartiles. The dummy indicating the lowest quartile is omitted and serves as an effective benchmark. We also use Core (Top Patent Class of the Firm) as a dummy indicating whether the patent is in the top patenting class of the bankrupt firm. For patent age, I(Young Patent) equals one if the patent was granted up to six years before the bankruptcy filing. Scaled Citations is the number of citations received in the first three years of a patent's life, scaled by the three-year citation of patents from its own vintage and technology class. Redeployability captures the extent that the patent is utilized by firms other than the owning firm, and MFT Liquidity captures the liquidity of the market specific to the patent's technology class. More details regarding those variables are described in the Appendix. In columns (1) to (5), the sample includes patents owned by all bankrupt public firms between 1981 and 2012; in column (6), we include patents owned by the sample of bankrupt firms that eventually emerged from bankruptcy; in column (7), we include firms that appear to be in financial but not economic distress (top tercile leverage and top tercile ROA); in column (8) we focus only on patents that were applied and granted within five years prior to the bankruptcy filing. All specifications include firm fixed effects. The t-statistics based on robust standard errors clustered at the firm level are displayed in parentheses. ${ }^{* *},{ }^{* *}$, and ${ }^{*}$ indicate significance at the $1 \%$, $5 \%$, and $10 \%$ levels, respectively. 
Table 4. Heterogeneous Effects Across Senior Creditor Control

Panel A: Heterogeneities across secured debt ratio

\begin{tabular}{|c|c|c|c|c|c|c|}
\hline \multirow[b]{3}{*}{ Secured Debt Ratio $=$} & \multicolumn{6}{|c|}{ Patent Being Sold $=1$} \\
\hline & $(1)$ & (2) & (3) & (4) & (5) & (6) \\
\hline & High & Low & Interacted & High & Low & Interacted \\
\hline Core & $\begin{array}{c}0.044^{* * *} \\
(8.226)\end{array}$ & $\begin{array}{c}0.005 \\
(1.034)\end{array}$ & $\begin{array}{c}0.005 \\
(1.052)\end{array}$ & & & \\
\hline Core x High & & & $\begin{array}{c}0.038^{* * *} \\
(5.090)\end{array}$ & & & \\
\hline $\mathrm{I}($ Core $)$ & & & & $\begin{array}{c}0.062^{* * *} \\
(19.596)\end{array}$ & $\begin{array}{c}-0.016^{* * *} \\
(-6.095)\end{array}$ & $\begin{array}{c}-0.016^{* * * *} \\
(-6.214)\end{array}$ \\
\hline $\mathrm{I}($ Core $) \times$ High & & & & & & $\begin{array}{c}0.078^{* * *} \\
(18.688)\end{array}$ \\
\hline Observations & 23,378 & 33,944 & 57,322 & 23,378 & 33,944 & 57,322 \\
\hline R-squared & 0.220 & 0.237 & 0.231 & 0.231 & 0.238 & 0.235 \\
\hline Controls & $\mathrm{Y}$ & $\mathrm{Y}$ & $\mathrm{Y}$ & $\mathrm{Y}$ & $\mathrm{Y}$ & $\mathrm{Y}$ \\
\hline Firm FE & Y & Y & $\mathrm{Y}$ & Y & Y & Y \\
\hline \multicolumn{7}{|c|}{ Panel B: Heterogeneities across time-series, pre- and post-2000 } \\
\hline Time period & $\begin{array}{c}(1) \\
\text { Post-2000 }\end{array}$ & $\begin{array}{c}(2) \\
\text { Pre-2000 } \\
\end{array}$ & $\begin{array}{c}(3) \\
\text { Interacted }\end{array}$ & $\begin{array}{c}(4) \\
\text { Post-2000 }\end{array}$ & $\begin{array}{c}(5) \\
\text { Pre-2000 }\end{array}$ & $\begin{array}{c}(6) \\
\text { Interacted }\end{array}$ \\
\hline Core & $\begin{array}{c}0.034^{* * *} \\
(8.040)\end{array}$ & $\begin{array}{c}-0.014^{* *} \\
(-2.052)\end{array}$ & $\begin{array}{c}-0.014 \\
(-1.319)\end{array}$ & & & \\
\hline Core x Post 2000 & & & $\begin{array}{c}0.049^{* * *} \\
(4.136)\end{array}$ & & & \\
\hline $\mathrm{I}($ Core $)$ & & & & $\begin{array}{c}0.027 * * * \\
(11.955)\end{array}$ & $\begin{array}{l}-0.003 \\
(-0.727)\end{array}$ & $\begin{array}{l}-0.003 \\
(-0.468)\end{array}$ \\
\hline $\mathrm{I}($ Core $) \times$ Post 2000 & & & & & & $\begin{array}{c}0.030^{* * *} \\
(4.075)\end{array}$ \\
\hline Observations & 57,175 & 5,595 & 62,770 & 57,175 & 5,595 & 62,770 \\
\hline R-squared & 0.281 & 0.516 & 0.294 & 0.282 & 0.516 & 0.295 \\
\hline Controls & Y & Y & $\mathrm{Y}$ & $\mathrm{Y}$ & $\mathrm{Y}$ & $\mathrm{Y}$ \\
\hline Firm FE & $\mathrm{Y}$ & $\mathrm{Y}$ & $\mathrm{Y}$ & $\mathrm{Y}$ & $\mathrm{Y}$ & $\mathrm{Y}$ \\
\hline
\end{tabular}


Notes. This table presents how the phenomenon of selling core patents varies depending on the senior creditor control. Senior creditor control is captured using the fraction of secured debt in total debt (Panel A) and time of bankruptcy filing (Panel B). In Panel A, secured debt ratio is defined as the fraction of secured debt in total debt of the bankrupt firm using information from Capital IQ and SEC filings. The analysis is conducted on a patent-level data set, and each observation is a patent $p$ in a bankrupt firm $i$ 's patent portfolio in the year of bankruptcy filing. In columns (1), (2), (4), and (5), the sample is split based on Secured Debt Ratio, and then we run the main specification as in Table 3 separately. In columns (3) and (6), we present results in which we interact Core with the dummy indicating high secured debt ratio, and the estimation is performed on the full sample. As a result, the coefficient on Core $\times$ High tests whether the pattern of selling core assets is significantly different for firms with high versus low senior creditor control.

Panel B follows the identical design but focuses on the heterogeneity across time series. In columns (1), (2), (4), and (5), the sample is split based on whether the bankrupt firm filed before or after 2000, and then we run the main specification as in Table 3 separately. In columns (3) and (6), we present results in which we interact Core with the dummy indicating Post-2000. As a result, the coefficient on Core $\times$ Post 2000 tests whether the pattern of selling core assets is significantly different for firms that filed bankruptcy before vs. after 2000 .

The dependent variable $S o l d_{i p}$ is a dummy variable indicating whether patent $p$ is sold during the bankruptcy reorganization process (from bankruptcy filing to the confirmation of the reorganization plan) by its owning firm $i$. Core is the distance between the patent and the firm's core technological expertise as defined in Section 2, with parameters $\iota=0.66$. I(Core) is a dummy variable indicating whether the patent is at the within-firm top quartile. All regressions include control variables I(Young Patent), Scaled Citations, Redeployability, and MFT Liquidity as defined in the text. All specifications include firm fixed effects. The t-statistics based on robust standard errors clustered at the firm level are displayed in parentheses. ${ }^{* *},{ }^{* *}$, and $*$ indicate significance at the $1 \%, 5 \%$, and $10 \%$ levels, respectively. 
Table 5. Creditor Rights, Patent Collateral, and Patent Sales in Bankruptcy

Panel A: Core Innovation and Patent Collateralization

\begin{tabular}{|c|c|c|c|c|}
\hline & & Collat & $\mathrm{cal}=1$ & \\
\hline & (1) & $(2)$ & $(3)$ & (4) \\
\hline Core & $\begin{array}{c}0.188^{* * *} \\
(5.000)\end{array}$ & $\begin{array}{c}0.200^{* * *} \\
(5.111)\end{array}$ & & \\
\hline $\mathrm{I}($ Core $)$ & & & $\begin{array}{c}0.191^{* * *} \\
(5.687)\end{array}$ & $\begin{array}{c}0.197^{* * *} \\
(5.885)\end{array}$ \\
\hline Scaled Citation & $\begin{array}{c}0.004 \\
(1.188)\end{array}$ & $\begin{array}{c}0.003 \\
(1.112)\end{array}$ & $\begin{array}{c}0.004 \\
(1.199)\end{array}$ & $\begin{array}{c}0.003 \\
(1.147)\end{array}$ \\
\hline Redeployability & & $\begin{array}{c}0.033^{* *} \\
(2.433)\end{array}$ & & $\begin{array}{c}0.031^{* *} \\
(2.415)\end{array}$ \\
\hline Observations & 63,496 & 63,496 & 63,496 & 63,496 \\
\hline R-squared & 0.175 & 0.176 & 0.185 & 0.186 \\
\hline Grant Year FE & $\mathrm{Y}$ & $\mathrm{Y}$ & $\mathrm{Y}$ & $\mathrm{Y}$ \\
\hline Technology Class FE & $\mathrm{Y}$ & $\mathrm{Y}$ & $\mathrm{Y}$ & $\mathrm{Y}$ \\
\hline
\end{tabular}

Notes. This table studies the determinants of patent collateral, and the reallocation of collateralized patents in and out of the bankruptcy process.

In Panel A, we perform a cross-sectional regression to explore the determinants of whether a patent is required to be collateralized by a creditor. The sample is all USPTO-granted patents through 2013 that belong to a bankrupt firm at bankruptcy filing. Patent collateral dummy Collateral is coded using the USPTO patent assignment database. All other variables are defined in the Appendix. We control for grant year and technology class fixed effects, and standard errors are clustered at both the technology class and grant year level. ${ }^{* * *},{ }^{* *}$, and ${ }^{*}$ indicate significance at the $1 \%, 5 \%$, and $10 \%$ levels, respectively.

Panel B: Patent Collateralization and Patent Sales

\begin{tabular}{lcccc}
\hline & \multicolumn{4}{c}{ Patent Being Sold $=1$} \\
\cline { 2 - 5 } & $(1)$ & $(2)$ & $(3)$ & $(4)$ \\
I(Collateralized) x I(In Bankruptcy) & $0.071^{* *}$ & $0.055^{* *}$ & $0.068^{* *}$ & $0.055^{* *}$ \\
& $(1.976)$ & $(2.309)$ & $(2.057)$ & $(2.381)$ \\
I(In Bankruptcy) & 0.012 & & 0.000 & \\
& $(1.402)$ & & $(0.017)$ & \\
I(Collateralized) & -0.011 & -0.003 & -0.012 & -0.007 \\
& $(-0.838)$ & $(-0.315)$ & $(-0.826)$ & $(-0.549)$ \\
Core x I(In Bankruptcy) & & & 0.023 & $0.019^{* *}$ \\
Core & & & $(1.562)$ & $(2.328)$ \\
& & & $-0.018^{*}$ & $-0.016^{* *}$ \\
Observations & & & $(-1.788)$ & $(-2.177)$ \\
R-squared & 470,254 & 470,254 & 470,254 & 470,254 \\
Controls & 0.172 & 0.334 & 0.168 & 0.335 \\
Year FE & Y & Y & Y & Y \\
Firm FE & Y & & Y & \\
Year x Firm FE & Y & Y & & Y \\
\hline
\end{tabular}


Notes. Panel B explores the reallocation of collateralized patents in and out of the bankruptcy process. The sample is a patent-year level data set of all patents owned by a firm that eventually filed for Chapter 11 bankruptcy, from three years before to three years after filing. I(Collateralized) is a dummy variable indicating whether the patent is collateralized. I(In Bankruptcy) is a dummy variable indicating whether the firm that owns the patent is undergoing the bankruptcy process. All regressions include control variables I(Young Patent), Scaled Citations, Redeployability, and MFT Liquidity as defined in the text. We control for firm and year fixed effects in column (1) and firm-by-year fixed effects in column (2). The t-statistics based on robust standard errors clustered at the firm level are displayed in parentheses. ${ }^{* * *},{ }^{* *}$, and ${ }^{*}$ indicate significance at the $1 \%, 5 \%$, and $10 \%$ levels, respectively.

Panel C: Creditor Control and the Sale of Collateralized Patents

\begin{tabular}{|c|c|c|c|}
\hline \multirow[b]{3}{*}{ Creditor Control $=$} & \multicolumn{3}{|c|}{ Patent Being Sold $=1$} \\
\hline & $(1)$ & $(2)$ & $(3)$ \\
\hline & High & Low & Interacted \\
\hline I(Collateralized) & $\begin{array}{c}0.158^{* * *} * \\
(4365)\end{array}$ & 0.066 & 0.066 \\
\hline I(Collateralized) $x$ High Secured Debt Ratio & & & $\begin{array}{l}0.092^{*} \\
(1.687)\end{array}$ \\
\hline Observations & 23,378 & 33,944 & 57,322 \\
\hline R-squared & 0.293 & 0.248 & 0.265 \\
\hline Controls & $\mathrm{Y}$ & Y & Y \\
\hline Firm FE & $\mathrm{Y}$ & $\mathrm{Y}$ & Y \\
\hline
\end{tabular}

Notes. Panel C presents how the phenomenon of selling collateralized patents varies depending on the secured debt ratio. The dependent variable Sold $_{i p}$ is a dummy variable indicating whether patent $p$ is sold during the bankruptcy reorganization process (from bankruptcy filing to the confirmation of the reorganization plan) by its owning firm $i$. I(Collateralized) is a dummy variable indicating whether the patent is collateralized. High Secured Debt Ratio is a dummy variable representing high secured debt ratio, as defined in Table 4 Panel A. All regressions include control variables I(Young Patent), Scaled Citations, Redeployability, and MFT Liquidity as defined in the text. All specifications include firm fixed effects. The t-statistics based on robust standard errors clustered at the firm level are displayed in parentheses. ${ }^{* * *},{ }^{* *}$, and ${ }^{*}$ indicate significance at the $1 \%, 5 \%$, and $10 \%$ levels, respectively. 
Table 6. DIP, Secured Debt, and the Sale of Core Patents

\begin{tabular}{lcc}
\hline & $\begin{array}{c}\text { Patent Being Sold }=1 \\
(1)\end{array}$ & $(2)$ \\
& Core $(\iota=0.66)$ & Core $(4$ th Quartile) \\
\cline { 2 - 3 } Core $\times$ DIP $\times$ High Secured Debt Ratio & $0.050^{* *}$ & $0.104^{* * *}$ \\
Core $\times$ High Secured Debt Ratio & $(2.464)$ & $(8.710)$ \\
Core $\times$ DIP & -0.004 & -0.010 \\
Core & $(-0.209)$ & $(-0.870)$ \\
& -0.013 & $-0.037^{* * *}$ \\
Observations & $(-1.073)$ & $(-5.421)$ \\
R-squared & 0.017 & $0.014^{* *}$ \\
Firm FE & $(1.512)$ & $(2.231)$ \\
\hline
\end{tabular}

Notes. This table presents how the phenomenon of selling core patents varies with the use of DIP financing. The dependent variable Sold $_{i p}$ is a dummy variable indicating whether patent $p$ is sold during the bankruptcy reorganization process (from bankruptcy filing to the confirmation of the reorganization plan) by its owning firm $i$. DIP is a dummy variable indicating whether the case involves DIP financing. High Secured Debt Ratio is a dummy variable representing high secured debt ratio, as defined in Table 4 Panel A. All regressions include control variables I(Young Patent), Scaled Citations, Redeployability, and MFT Liquidity as defined in the text. All specifications include firm fixed effects. The t-statistics based on robust standard errors clustered at the firm level are displayed in parentheses. ${ }^{* * *},{ }^{* *}$, and ${ }^{*}$ indicate significance at the $1 \%, 5 \%$, and $10 \%$ levels, respectively. 
Table 7. The Incentives of Secured Creditors

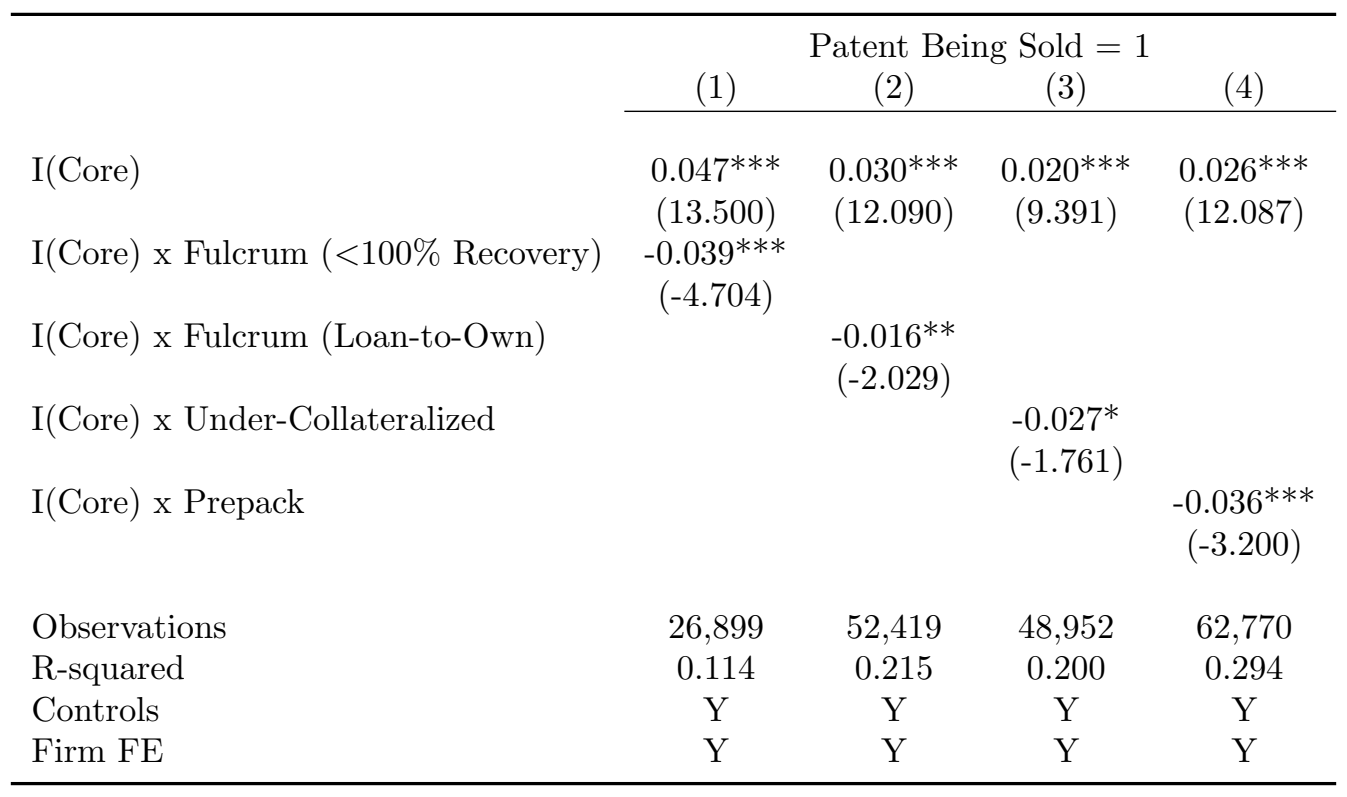

Notes. This table presents how the phenomenon of selling core patents varies depending on the incentives of secured creditors. The analysis is conducted on a patent-level data set, and each observation is a patent $p$ in a bankrupt firm $i$ 's patent portfolio in the year of bankruptcy filing. In column (1), we interact Core with the dummy indicating that secured creditors' recovery rate is less than $100 \%$ post-bankruptcy. In column (2), we interact Core with the dummy indicating secured creditors received newly issued equity of reorganized firms ("Loan-to-Own"). In column (3), we define firms with the value of secured debt to book assets equals to or larger than one as under-collateralized. We present results in which we interact Core with the dummy indicating under-collateralization among firms with non-zero secured debt. In column (4), we interact Core with the dummy indicating the case is prepackaged.

The dependent variable $\operatorname{Sold}_{i p}$ is a dummy variable indicating whether patent $p$ is sold during the bankruptcy reorganization process (from bankruptcy filing to the confirmation of the reorganization plan) by its owning firm $i$. Core is the distance between the patent and the firm's core technological expertise as defined in Section 2, with parameters $\iota=0.66$. I(Core) is a dummy variable indicating whether the patent is at the within-firm top quartile. All regressions include control variables I(Young Patent), Scaled Citations, Redeployability, and MFT Liquidity as defined in the text. All specifications include firm fixed effects. The t-statistics based on robust standard errors clustered at the firm level are displayed in parentheses. ***, **, and ${ }^{*}$ indicate significance at the $1 \%, 5 \%$, and $10 \%$ levels, respectively. 
Table 8. Patent Trolls, Patent Litigation, and Innovation Sales in Bankruptcy

Panel A: Probability of selling innovation to NPEs

\begin{tabular}{lcccc}
\hline & \multicolumn{4}{c}{ Sold to Patent Troll $=1$} \\
& $(1)$ & $(2)$ & $(3)$ & $(4)$ \\
\cline { 2 - 5 } I(In Bankruptcy) & $0.005^{* * *}$ & $0.005^{* * *}$ & $0.020^{* * *}$ & $0.020^{* * *}$ \\
& $(3.848)$ & $(3.699)$ & $(8.728)$ & $(8.867)$ \\
& & & & \\
Observations & 204,740 & 204,740 & 204,505 & 204,505 \\
R-squared & 0.000 & 0.001 & 0.291 & 0.292 \\
Year FE & & $\mathrm{Y}$ & & $\mathrm{Y}$ \\
Firm FE & & & $\mathrm{Y}$ & $\mathrm{Y}$ \\
\hline
\end{tabular}

Panel B: Likelihood of litigation and patent sales

\begin{tabular}{|c|c|c|c|c|c|c|}
\hline \multirow[b]{3}{*}{ Litigation Risk $=$} & \multicolumn{6}{|c|}{ Patent Being Sold $=1$} \\
\hline & $(1)$ & $(2)$ & $(3)$ & (4) & $(5)$ & $(6)$ \\
\hline & High & Low & Interacted & High & Low & Interacted \\
\hline Core & $\begin{array}{c}0.049 * * * \\
(8.553)\end{array}$ & $\begin{array}{c}0.013^{* *} \\
(2.466)\end{array}$ & $\begin{array}{c}0.010^{* *} \\
(2.255)\end{array}$ & & & \\
\hline Core x High & & & $\begin{array}{c}0.035^{* * *} \\
(9.513)\end{array}$ & & & \\
\hline $\mathrm{I}($ Core $)$ & & & & $\begin{array}{c}0.035^{* * *} \\
(11.126)\end{array}$ & $\begin{array}{c}0.013^{* * *} \\
(4.742)\end{array}$ & $\begin{array}{c}0.010^{* * *} \\
(3.426)\end{array}$ \\
\hline I(Core) $x$ High & & & & & & $\begin{array}{c}0.028^{* * *} \\
(7.504)\end{array}$ \\
\hline Observations & 31,303 & 31,467 & 62,770 & 31,303 & 31,467 & 62,770 \\
\hline R-squared & 0.297 & 0.309 & 0.294 & 0.298 & 0.309 & 0.295 \\
\hline Controls & Y & Y & $\mathrm{Y}$ & Y & $\mathrm{Y}$ & $\mathrm{Y}$ \\
\hline Firm FE & Y & Y & $\mathrm{Y}$ & Y & Y & $\mathrm{Y}$ \\
\hline
\end{tabular}

Notes. This table studies the role of patent trolls and patent litigation in patent sales in bankruptcy. In Panel A, we construct a sample of all patent transactions between 1981 and 2015, and we explore the probability that the patent is sold to a patent troll. The key explanatory variable is a dummy variable indicating whether the patent sale happens when the seller is in bankruptcy.

Panel B studies whether the patent selling pattern differs depending on the litigation risks of the different technology classes. Litigation risk is defined using the ratio of litigated patents in a technology class. The analysis is conducted on a patent-level data set, and each observation is a patent $p$ in a bankrupt firm $i$ 's patent portfolio in the year of bankruptcy filing. In columns (1), (2), (4), and (5), the sample is split based on the Litigation Risk, and then we run the main specification as in Table 3 separately. In columns (3) and (6), we present results in which we interact Core with the dummy indicating high litigation risk, and the estimation is performed on the full sample. As a result, the coefficient on Core $\times$ High tests whether the pattern of selling core assets is significantly different for patents with higher litigation risks. Core is the distance between the patent and the firm's core technological expertise as defined in Section 2, with parameters $\iota=0.66$. I (Core) is a dummy variable indicating whether the patent is at the within-firm top quartile. All regressions include control variables I(Young Patent), Scaled Citations, Redeployability, and MFT Liquidity as defined in the text. All specifications include firm fixed effects. The t-statistics based on robust standard errors clustered at the firm level are displayed in parentheses. ${ }^{* * *},{ }^{* *}$, and $*$ indicate significance at the $1 \%, 5 \%$, and $10 \%$ levels, respectively. 